\title{
Geophysical characterization of mantle melting anomalies: a crustal view
}

Valentí Sallarès $\left(1,{ }^{*}\right)$ and Alcinoe Calahorrano (2)

(1) Marine Technology Unit - CMIMA - CSIC, Barcelona, Spain

(2) Institute of Marine Sciences - CMIMA - CSIC, Barcelona, Spain

(*) Contact address:

Unitat de Tecnologia Marina (UTM) - CMIMA - CSIC

Passeig Maritim de la Barceloneta 37-49, 08003 Barcelona, Spain

Ph. $+34-932309623$

Fax. $+34-932309555$

Email.vsallares@cmima.csic.es

\section{ABSTRACT}

At present there is no single, "unified theory" capable of explaining the variety of geological, geophysical, and geochemical observations that characterize what is generically known as hotspot magmatism. An increasing number of geophysical and geochemical observations disagree with the predictions of the conventional thermal plume model, in which excess melting is mainly due to high mantle temperatures. Other parameters such as the presence of water or the composition of the mantle source have been shown to be as important as temperature in controlling the structure and physical properties of the igneous crust. In this manuscript we first emphasize the importance of doing proper velocity and density modelling including comprehensive uncertainty analysis to determine how well resolved the geophysical parameters actually are. We show that in some cases the contribution of velocity-derived lateral crustal density variations can be sufficiently significant to account for the observed gravity and topography anomalies without calling for noticeable mantle density contrasts. Second, we show that the comparison of crustal geometry obtained along age-progressive volcanic tracks enables temporal variations of the hotspot-ridge distance to be estimated. Finally, we use a 2-D mantle melting model to illustrate what is the effect of different mantle melting parameters on the resulting crustal structure. The tests made indicate that is difficult to find a plausible combination of mantle temperature, upwelling rate, melt productivity, and thickness of the melting zone to explain either high-velocity, underplated bodies frequently described at mid-plate settings, nor the lack of a positive crustal thickness-velocity $\left(\mathrm{H}-\mathrm{V}_{\mathrm{p}}\right)$ correlation found at igneous provinces originated on-ridge. We suggest that the main 
parameter controlling the generation of volcanic underplating is the presence of a lithospheric lid limiting the extent of the mantle melting zone, whereas the $\mathrm{H}-\mathrm{V}_{\mathrm{p}}$ anti-correlation can be related to the presence of a major-element heterogeneity, such as eclogite derived from recycled oceanic lithosphere, in the mantle source.

\section{INTRODUCTION}

Large igneous provinces, oceanic plateaus, flood basalts, and aseismic ridges constitute some of the largest manifestations of terrestrial magmatism, but their origin and the melting processes and underlying mantle dynamics necessary to generate them are still poorly understood. From here on, we refer to this type of magmatism as "hotspot magmatism" to denote a locality where excess magma is produced, not as a sign of high temperature. Similarly, we refer to its diverse surface expressions by the generic name of "igneous provinces", and to the source of both as "melting anomaly". One of the common characteristics of hotspot magmatism is that it does not necessarily occur near the boundaries between tectonic plates and, therefore, it does not seem to be directly related to the main plate tectonic cycle. Whereas normal oceanic crust is presumed to originate by decompression melting of normal oceanic mantle $\left(\sim 1300^{\circ} \mathrm{C}\right.$ temperature, pyrolitic in composition) upwelling passively beneath a spreading center, and arc volcanism is widely accepted to be the remnant of melts originating within the mantle wedge by water expelled from the dehydrating subducting slab at convergent margins, hotspot magmatism can occur nearly anywhere on Earth (Figure 1).

The most widely accepted model to explain the occurrence of hotspot magmatism is the thermal plume model (Wilson, 1963; Morgan, 1971), in which hot, buoyant mantle plumes resulting from thermal instabilities at the core-mantle boundary rise to the surface and produce large amounts of melt. The presence of deep mantle plumes is consistent with continuous low-velocity anomalies underlying several active hotspots that extend from the surface to the lower mantle shown by global tomography models (e.g. Zhao, 2001; Montelli et al., 2004). Given that they are anchored in the deep mantle, the kinematics of mantle plumes must be decoupled from the main plate tectonic cycle, so they can qualitatively explain the apparent fixity of the hotspot framework, the widespread occurrence of intra-plate magmatism, and the formation of age-progressive volcanic tracks. In the thermal plume model, elevated temperatures cause mantle melting, and an excess of MgO-rich (olivine-rich) 
melt is mostly emplaced to form thick, high-velocity igneous crust (e.g. White and McKenzie, 1989). Igneous provinces are generally characterized by prominent topography and gravity anomalies (e.g. Anderson et al., 1973). Seismic investigations show, in turn, that potential field anomalies are partly or totally compensated by the presence of thick crustal roots (e.g. Darbyshire et al., 2000; McNutt and Bonneville, 2000; Korenaga et al., 2001; Sallarès et al., 2003).

Although there is general agreement in that long-lived, deep-seated thermal mantle plumes constitute an attractive explanation for the occurrence of hotspot magmatism, there is an increasing number of observations that do not agree with the predictions of this classical model. It is interesting to note, for instance, that first-order hotspots such as Iceland or Galápagos, show low-velocity tomography anomalies that are confined to the upper mantle only (Montelli et al., 2004), and the estimated lower crustal velocity for a number of igneous provinces (e.g. Kerguelen, Galápagos, North-Atlantic igneous province) is lower than expected for melting of hotter-than-normal mantle (e.g. Charvis and Operto, 1999; Sallarès et al. 2003; Korenaga et al., 2000).

What seems evident at the present day is that excess mantle temperature is not the only factor that may explain enhanced hotspot magmatism and, in some special cases, it has been questioned if temperature is significant at all (e.g. Green et al., 2001; Green and Falloon, 2005). Mantle composition, water content, upwelling rates, or the melting process itself have been shown to be as important as temperature in controlling the amount of melt produced as well as the geophysical and geochemical properties of igneous rocks (e.g. Ito et al., 1999; Maclennan et al., 2001; Cushman et al., 2004). Enhanced melting has been attributed to the presence of lower melting components, such as eclogite derived from recycled oceanic crust, or to the influence of deep damp melting for a number of hotspots including Hawaii (e.g. Sobolev et al., 2000), Açores (e.g., Schilling et al., 1983; Bonatti, 1990), Iceland (e.g., Ito et al., 1999; Foulger and Anderson, 2005) and Galápagos (e.g., Cushman et al., 2004; Sallarès et al., 2005). It is therefore likely that excess melting (and thicker crust) is not produced by a single, well-defined mechanism (i.e. a thermal mantle plume) but it can be the product of several different processes that must be examined and characterized case by case.

In this manuscript we emphasize the importance of performing an integrated approach combining geophysical methods with geological and geochemical observations to systematically characterize the structure, physical properties, melt volume, and composition of the crustal igneous rocks, which are the final product of any melting process. Systematic crustal characterization will help constrain the parameters that govern the mantle melting 
process in each particular case, and can be used as input into geodynamic models to gain quantitative understanding of the underlying mantle dynamics.

The rest of this manuscript is organized in two sections. In section 2, we first summarise geophysical observations at different igneous provinces, its differences, and their relationships with the mode of crustal emplacement. Then, we describe a procedure for obtaining crustal velocity and density models, and we discuss the importance of performing accurate modelling together with a comprehensive analysis of model parameter uncertainties, in order to estimate reliably the structure and physical properties of the igneous crust. In section 3, we present recent advances on the characterization of mantle melting parameters based on crustal structure information. Then we explain how to estimate the intensity of a melting anomaly based on crustal thickness observations. Finally, we illustrate the effects of the different parameters that characterise mantle melting on the resulting seismic structure of the igneous crust, and we compare the predictions of the mantle melting model with observations made at different igneous provinces.

\section{STRUCTURE AND PHYSICAL PROPERTIES OF IGNEOUS PROVINCES}

From a geophysical point of view, igneous provinces are segments of anomalous oceanic crust characterized by (1) bathymetric swells showing shallow and rough seafloor over areas ranging from $10^{4}$ to $10^{6} \mathrm{~km}^{2},(2)$ associated prominent, wide potential field anomalies encompassing the volcanic edifices, (3) estimated melt volumes that can exceed $10^{7} \mathrm{~km}^{3}$, emplaced to form thicker-than-normal igneous crust (e.g. Coffin and Eldholm, 1994). Whereas normal oceanic crust generated at spreading centres is around 6-7 km-thick (White et al., 1992), the crust of igneous provinces is generally thicker than $15 \mathrm{~km}$ (Charvis et al., 1999; Ye et al., 1999; Grevemeyer et al., 2001; Sallarès and Charvis, 2003) and, in extreme cases like Iceland or the Ontong Java plateau, it can exceed $30 \mathrm{~km}$ (Darbyshire et al., 1998; Miura et al., 2004). In terms of seismic velocity $\left(\mathrm{V}_{\mathrm{p}}\right)$ (and likewise for density), the igneous crust comprises two layers. The upper layer (oceanic Layer 2, including sediments and upper crust) is characterized by large vertical $V_{p}$ (density) gradients, with $V_{p}$ ranging from $\sim 2.0 \mathrm{~km} / \mathrm{s}$ to $\sim 6.5 \mathrm{~km} / \mathrm{s}$, whereas the lower layer (oceanic Layer 3) shows much more uniform $\mathrm{V}_{\mathrm{p}}(6.5-7.5 \mathrm{~km} / \mathrm{s})$.

Depending on whether the mantle melting anomaly is located near or far from a spreading center, the internal architecture of the crust as well as the relative thickness of the 
two layers can vary considerably. To illustrate these effects, we show in Table I a compilation of seismic observations made at several igneous provinces, some of which are believed to have originated off-ridge and others on-ridge. Thus, when a melting anomaly is located beneath or in the vicinity of a spreading centre, the crust is thought to be generated in a single step. The mantle wells up in response to seafloor spreading and melts from the base of the mantle melting zone up to the surface. The mode of crustal emplacement and resulting crustal structure is in this case similar to that of normal oceanic crust. Some examples of this are the Ontong-Java, North Atlantic or Galápagos Volcanic Provinces (GVP) (see Table I). As shown in this Table, the main difference is the thicker crust with respect to that of normal oceanic crust. Regardless of crustal thickness variations, the ratio of Layer 2 thickness versus total crustal thickness is quite uniform (around $25 \%$ ), indicating that Layer 3 accommodates most of the crustal overthickening (Mutter and Mutter, 1993), and the mean Layer 3 velocity is similar to that of normal oceanic crust (White et al. 1992).

When the melting anomaly is mid-plate, far from spreading centres, the total melt production is limited by the presence of a mechanical boundary (i.e., a cold lithospheric lid) that restricts the minimum depth at which melt can be generated and thus the total amount of melting. This is the reason why mid-plate igneous provinces (e.g. Hawaii, Réunion) tend to have thinner crust than those generated beneath spreading centres (e.g. Iceland, Ontong-Java), even if the melting anomaly is potentially stronger. In this case, part of the melt is believed to accumulate at the base of the crust, thickening it by crustal underplating, and part is extruded and piled on top of the pre-existing plate. This is the case, for example, for the Hawaii, Canary, Réunion and Marquesas Islands (see Table I). The ratio of Layer 2 thickness versus total crustal thickness is higher than in the case of igneous provinces generated at a spreading center (around $50 \%$ ), and the underplated bodies are typically characterized by moderate thickness $(\sim 5 \mathrm{~km})$ and high $\mathrm{V}_{\mathrm{p}}$ (in excess of $7.3 \mathrm{~km} / \mathrm{s}$ ).

In general, the $V_{p}$ /density gradient of Layer 2 largely reflects lithological variations in the uppermost crust and diminishing alteration and porosity/fracturing of igneous rocks with depth (Bratt and Purdy, 1984; Detrick et al., 1994). The physical properties of Layer 3 and those of the underplated bodies are thus considered to be a good proxy for those of the mostly unaltered, crack-free gabbroic rocks that probably predominate at lower crustal levels (e.g. Kelemen and Holbrook, 1995). It is therefore important to confidently determine Layer $3 \mathrm{~V}_{\mathrm{p}}$ and density as well as their uncertainties in order to link these "measurable values" with the parameters that govern mantle melting. In the next sections we describe a possible procedure for doing this. 


\subsection{Crustal Seismology}

\subsubsection{Seismic Modelling and Uncertainty Analysis}

Wide-angle reflection and refraction seismics (WAS) constitute the most commonly used geophysical method to study the structure of the crust. Depending on the acquisition layout and the modelling technique, the method has the potential to yield velocity models with a spatial resolution better than $1 \mathrm{~km}$. In a classical marine survey, a number of Ocean Bottom Seismometers (OBS) deployed on the sea floor record successive airgun shots generated at the sea surface. WAS data are represented by offset-travel-time diagrams called record sections that show seismic phases refracted within the crust and upper mantle and reflected at the main discontinuities (Figure 2b). In contrast to Multichannel Seismics (MCS), WAS record sections do not provide direct images of the sub-seafloor structure, so it is necessary to construct velocity models to account for the data. At present, the most widely used modelling technique is traveltime tomography (e.g. Zelt and Barton, 1998, Korenaga et al., 2000), in which the velocity field and the reflectors' geometry are simultaneously calculated from the joint inversion of travel times of reflected and refracted phases (Figure $2 c)$.

Owing to the nature of the joint refraction/reflection inverse problem, there are two main issues that have to be addressed before interpreting the results. The first is related to the non-uniqueness of the inversion solution, which means that the final solution depends on the starting velocity model. The second concerns estimating the model uncertainties, which is essential to confidently relate $V_{p}$ to mantle melting parameters. It has been shown that the only practical way to address both issues is to perform Monte Carlo-type analysis (e.g. Tarantola, 1987). The degree of dependence of the solution obtained on the initial model can be assessed by conducting a number of inversions with a variety of randomly generated initial models and noisy data sets (e.g. Sallarès et al., 2005). If all models have the same probability and the initial models cover the full region of non-null probability within the parameter space, the a posteriori covariance of the solutions obtained can be interpreted as a statistical measure of the solution uncertainty (Tarantola, 1987). One alternative to Monte Carlo analysis is to calculate the errors from the model Hessian (e.g. Hobro et al., 2002). However, the diagonal elements of the a posteriori covariance calculated from the Hessian can be interpreted as a posteriori errors (uncertainty) only when the problem is linearizable in all the region of 
significant posteriori probability density, which is not easy to estimate a priori (Tarantola, 1987).

A third issue is related to the inherent trade-off between depth and velocity parameters in reflection tomography (Bickel, 1990). This is especially important if the purpose is to determine the velocity of oceanic Layer 3. As stated above, the velocity gradient within Layer 3 is small, so refracted waves do not penetrate deep into that layer. Therefore, both Layer 3 velocity and the geometry of the crust-mantle boundary (i.e. the Moho) must be determined using Moho reflections only, and the trade-off must be estimated by comparing the results of the inversion using different values of the depth-kernel weighting parameter (Korenaga et al., 2000).

\subsubsection{Velocity Structure of Igneous Provinces}

Most existing melting models assume that, once mantle melts, the magma rises through the lithosphere and is eventually emplaced to form igneous crust. The crustal volume, as well as the physical properties of the igneous rocks produced, depend on the temperature, composition, and upwelling rate of the mantle source. Infinite lithospheric stretching over normal temperature, pyrolitic mantle, produces melt with a Mid-Ocean Ridge Basalts (MORB)-like composition that crystallizes to form igneous crust with a mean $V_{p}$ of $\sim 7.0 \mathrm{~km} / \mathrm{s}$ (McKenzie and Bickle, 1988; White et al., 1992). As potential temperature $\left(\mathrm{T}_{\mathrm{p}}\right)$ rises above normal, the $\mathrm{MgO}$ content of the melt also increases, basically due to its larger olivine component. The $\mathrm{V}_{\mathrm{p}}$ of igneous crust is mainly controlled by this $\mathrm{MgO}$ content: higher $\mathrm{MgO}$ content implies higher $V_{p}$. White and McKenzie (1989) showed that if $T_{p}$ is increased by about $200^{\circ} \mathrm{C}$ above normal, the mean velocity of igneous crust increases by as much as $0.2-$ $0.3 \mathrm{~km} / \mathrm{s}$. Therefore, if thick igneous crust is produced by melting of anomalously hot mantle, there should be a positive correlation between $V_{p}$ and crustal thickness. This is apparently the case for igneous provinces emplaced at mid-plate, far from spreading centres, such as Hawaii (Watts and Ten Brink, 1995), Canary (Ye et al., 1999; Canales et al., 2000), Marquesas (Caress et al., 1995), Réunion (Charvis et al., 1999) and the Ninetyeast ridge (Grevemeyer et al., 2001) (Table I), where the presence of thick, high-velocity crustal roots or underplated bodies have been attributed to the influence of postulated thermal anomalies.

In contrast, velocity models for igneous provinces near spreading centers, such as Kerguelen (Charvis and Operto, 1999), the North Atlantic Volcanic Province (Darbyshire et al., 1998; Korenaga et al., 2000), and the Cocos, Carnegie, and Malpelo aseismic ridges of the GVP (Sallarès et al. 2003; 2005), do not show higher-than-normal lower crustal velocity, but 
velocity that progressively increases between the top and the base of Layer 3, similar to that observed in normal oceanic crust (e.g. White et al., 1992). The lack of a positive correlation between $V_{p}$ and crustal thickness does not agree, therefore, with the predictions of the conventional thermal plume model.

It is, however, important to perform comprehensive uncertainty analysis in order to relate the seismic structure to the parameters that characterize mantle melting. Historically, the classical way of obtaining velocity models from seismic data is by means of forward modelling. That requires varying the lower crustal velocity and Moho geometry by trial-anderror until an "acceptable" fit to the data is attained. Under those circumstances, it is not possible to formally quantify model parameter uncertainty. This makes it difficult to know to what extent lower crustal velocity is well resolved by the data or, in other words, what the trade-off is between crustal velocity and crustal thickness. Without this information, it is not possible to confidently relate the seismic parameters to those controlling the mantle melting process. An error of 3\% for a typical mean lower crustal velocity of $7.0 \mathrm{~km} / \mathrm{s}$, for example, means an error of $0.2 \mathrm{~km} / \mathrm{s}$, which almost completely precludes any possible petrological inference based on crustal velocity.

In contrast, joint refraction and reflection travel time tomography enables Monte Carlotype uncertainty analysis to be performed, including the effect of both traveltime picking errors and the dependence of the solution obtained on the initial model. This is the case for the models showing low-velocity lower crust in the Greenland margin (Korenaga et al., 2000) and the GVP (Sallarès et al., 2005). In these cases, alternatives or modifications to the thermal anomaly model need to be considered in explaining the geophysical observations. This is discussed in section 3.2 .

\subsection{Gravity Modelling and Compensation of Topography}

\subsubsection{Constructing Density Models}

Gravity analysis is commonly performed to estimate the density structure of the crust and upper mantle in hotspot-influenced areas (e.g. Ito and Lin, 1995, Darbyshire et al., 2000, Korenaga et al., 2001). It is important to characterize mantle density variations that may be associated with the presence of melting anomalies, which is critical to improve constraint on their nature. However, constructing a density model based on gravity data is prone to nonuniqueness, so it can become arbitrary unless a priori information is adequately incorporated into the modelling (see, e.g., Barton, 1986). A common way of doing this consists of 
subtracting the effects of the seafloor and an estimated crust-mantle boundary interface from the free-air gravity anomaly, and attributing the remaining anomaly to density variations in the upper mantle (e.g. Ito and Lin, 1995). This type of approach assumes, however, that crustal density is laterally uniform along the transect, which in some cases might be an oversimplification.

Clear examples in which lateral density variations can be significant are profiles crossing aseismic ridges from side to side. There, the crustal density distribution of the adjacent oceanic basins is different from that of the thickened ridge segments, as has been shown in the case of the GVP (Sallarès et al., 2005). When possible, it is therefore preferable to include reliable information on the lateral crustal density variations by jointly inverting, or combining, seismic and gravity data (e.g. Nielsen and Jacobsen, 2000, Korenaga et al., 2001). Seismic modelling is probably the best way of constraining the crustal structure, and then velocity-derived density models can be constructed based on existing velocity-density empirical relationships (e.g. Birch, 1961; Carlson and Herrick, 1990; Christensen and Mooney, 1995). Using the velocity model as a benchmark to infer the crustal and upper mantle density distribution requires, however, that (1) both the velocity field as well as the crust-mantle boundary geometry are well constrained by seismic data, and (2) the velocitydensity conversion is accurate enough.

As explained above, model parameter uncertainty can be quantified by performing a Monte Carlo-type analysis. Velocity uncertainty can be then propagated to density and to the calculated gravity anomaly. This way it is possible to accurately correct the crustal contribution to the gravity field, including the effects of topography, geometry of the crustmantle boundary, and vertical/lateral crustal density variations. The remaining gravity anomaly can be confidently attributed to mantle density contrasts. Concerning the velocitydensity conversion, for oceanic crust it is reasonable to assume one-step crustal production from mantle melting, so the velocity-density conversion is quite well constrained and relatively simple compared with that of continental crust, where a large variety of rock types exist (e.g. Christensen and Mooney, 1995). This is especially true for the crack-free, almost unaltered oceanic Layer 3, where velocity-density relationships for oceanic crust (e.g. Birch, 1961; Carlson and Herrick, 1990) can be used confidently to derive density from velocity.

\subsubsection{Joint Gravity and Topography Compensation Analysis.}

Topography compensation analysis is frequently carried out in combination with gravity modelling. Similar to gravity modelling, successful completion of this exercise requires 
incorporating a priori information on crustal structure, preferably a velocity-derived density model and crust-mantle boundary geometry based on WAS data modelling. As in the case of many gravity studies, the effect of lateral crustal density variations in the observed topography is often neglected. Isostatic equilibrium of topography is generally assumed to be a product of crustal thickness variations (i.e., Airy isostasy), lateral variations in the mantle density above a given compensation depth (i.e., Pratt isostasy), or, more likely, a combination of both (e.g. Ito and Lin, 1995).

As discussed in the previous section, however, neglecting lateral crustal density variations is not a valid assumption in the case of igneous provinces. As an example to illustrate the potential effect of lateral crustal density variations in the observed topography and gravity field, we compare in Figure 2 the predicted gravity anomaly and the calculated mantle density across the Cocos Ridge (GVP) for two models with the crustal geometry shown in Figure 2c but different crustal density distributions. The calculation was repeated for three different compensation depths - 50, 100, and $200 \mathrm{~km}$. Model I (Figure 2d) has a uniform crustal density of $2,900 \mathrm{~kg} / \mathrm{m}^{3}$, whereas the crustal density of Model II (Figure 2e) was derived from the velocity distribution shown in Figure 2c, using the velocity-density conversion law of Carlson and Herrick (1990), $\rho=3.61-6.0 / \mathrm{V}_{\mathrm{p}}$, for the upper crust, and that of Birch (1961), $\rho=\left(\mathrm{V}_{\mathrm{p}}+1.0\right) / 2.67$, for the lower crust. The reference mantle density is 3,300 $\mathrm{kg} / \mathrm{m}^{3}$ in both models.

For Model I, the maximum residual gravity anomaly is $\sim 40-50 \mathrm{mGal}$ (Figure $2 \mathrm{f}$ ) and predicted mantle density anomaly beneath the thickened part of the crust is as high as 30-40 $\mathrm{kg} / \mathrm{m}^{3}$ for $Z=50 \mathrm{~km}$ (Figure $2 \mathrm{~h}$ ). In contrast, the uncertainty in the predicted residual gravity anomaly for Model II (Figure 2g), which was obtained using the uncertainty of the velocity model of Figure $2 c$, is of the order of the remaining gravity anomaly. Similarly, estimated mantle density anomalies necessary to account for the observed topography are statistically insignificant, ranging from $\pm 5 \mathrm{~kg} / \mathrm{m}^{3}$ for $Z=50 \mathrm{~km}$ to $\pm 1 \mathrm{~kg} / \mathrm{m}^{3}$ for $Z=200 \mathrm{~km}$ (Figure 2i). This means that the contribution of lateral crustal density variations is sufficiently significant to account for the observed gravity and topography anomalies. If we do not consider the effect of lateral crustal density variations we could be tempted to assign an upper mantle origin to the remaining anomaly, which is unsupported by the data. In summary, we reiterate that very different density models can satisfy a given gravity/topography constraint, so it is crucial to include a priori information provided by WAS models, and to assess the uncertainty in model parameters, before interpreting the results. 
In this situation it is not possible to infer reliably mantle density information based on gravity and topography data, because if there is a mantle density anomaly, it is smaller than the uncertainty in the methods. Considering lateral crustal density (velocity) variations, especially in regions with laterally varying structure such as oceanic plateaus or aseismic ridges, is thus essential to confidently correct the crustal contributions to the gravity field and to lithospheric buoyancy.

\subsubsection{Density Structure of Igneous Provinces}

Gravity anomalies and topographic swells typically encompassing igneous provinces are believed to be sustained by a combination of crustal thickening and sub-lithospheric mantle density anomalies (e.g. Oxburgh and Parmentier, 1977; Phipps Morgan et al., 1995), but the relative importance of each factor to account for the observed anomalies remains unclear. Sub-lithospheric compensation models consider the primary source of buoyancy to be located in the mantle. Possible sources of buoyancy may be either mantle density variations associated to thermal anomalies (White and McKenzie, 1989), caused by melt depletion (Phipps Morgan et al., 1995), or a combination of both.

One example of the latter is the mantle plum-pudding model of Phipps Morgan and Morgan (1999), in which a heterogeneous, hot mantle composed of incompatible-element rich veins within a more depleted matrix wells up and melts in a two-stage process. The first stage corresponds to hotspot melting, in which deep, low-degree melts are extracted from the mantle mixture. Since incompatible-element rich veins are easier to melt, proportionally more of the incompatible elements are extracted from these components, forming ocean island basalts (OIB) as well as a residual column composed of a mixture of leftovers that is hot, buoyant and depleted in composition compared with normal mantle. In the second stage, depleted MORB are extracted beneath spreading centers from re-melting of the mixture of leftovers. In that case, the residual mantle column beneath hotspot swells would be expected to show detectable velocity and density anomalies. Similar models based on flow and melting of a heterogeneous mantle have been proposed to explain as well the geochemistry of OIB and MORB (Ito and Mahoney, 2005). Consistently, a recent study performed along the Galápagos hotspot-affected segment of the Cocos-Nazca spreading center (CNSC) (Figure 2a) indicated that the shoaling of the topographic swell as well as the decreasing gravity anomaly are sustained by (1) crustal thickening (which accounts for $\sim 50 \%$ of the anomaly), (2) thermal buoyancy ( $\sim 30 \%)$, and (3) chemical buoyancy arising from melt depletion $(\sim 20 \%)$ (Canales et al., 2002). The contribution of mantle anomalies is likely to be significant for 
oceanic swells located above active hotspots, as indicated by the presence of striking lowvelocity, deep-seated anomalies shown by global tomography models (Zhao, 2001; Montelli et al., 2004).

Alternatives to sub-lithospheric compensation are crustal compensation models, in which the swell is mainly supported by lateral variations of crustal density and thickness, with a minor contribution from mantle density anomalies. This may be the case for igneous provinces located away from the zone of direct hotspot influence. One example is the Marquesas swell, where buoyancy of the material underplating the island chain has been shown to be able to support almost completely the swell (McNutt and Bonneville, 2000). Another example is the case of the GVP (Figure 2), where the upper mantle density anomaly, if any, must be small, practically undetectable based on gravity and topography modelling. This means that the significance of compositional mantle buoyancy due to melt extraction and depletion may be, at least in some special cases, smaller than suggested by theoretical studies.

The importance of a proper crustal correction has been also pointed out in connection with the gravity highs observed at ocean-continent transition zones. These gravity highs have been typically associated with high-density crustal roots, in good agreement with the highvelocity lower crust frequently described beneath the transition zone of rifted continental margins (e.g. Kelemen and Holbrook, 1995). The presence high-velocity, high-density lower crust has usually been explained by melting of hotter-than-normal mantle. However, it has been recently demonstrated that velocity-derived lower crustal density of the eastern Greenland margin is too low to account for the observed gravity high (Korenaga et al., 2001). The most likely explanations are (1) the presence of a dense Fe-rich shallow mantle beneath the margin (i.e., a fertile, mild mantle source), and (2) denser upper crust compared with normal oceanic crust, in the ocean-continent transition zone.

\section{GEOPHYSICAL CONSTRAINTS THAT CHARACTERIZE THE MANTLE MELTING PROCESS}

A key connection between the physical properties that we can "measure" in volcanic rocks and those of the mantle source material is the mantle melting process. It is therefore essential establishing experimental relationships between the parameters governing the mantle melting process and the physical properties of the resulting crust, and including them in 
mantle melting models to enable direct comparisons between the geophysical observations and the predictions made for a given set of parameters.

In this section we first explain how we estimate variations in the amount of magma supplied (i.e. the volumetric melt flux) and the relative distance between a mid-oceanic ridge and the centre (i.e. the point of maximum intensity) of a melting anomaly. Second, we use a steady-state, 2-D mantle melting model to illustrate the effects of the different parameters that characterize mantle melting (upwelling rate, melt productivity, water content, presence of a lithospheric lid, composition) on the resulting seismic structure of the igneous crust, and we compare the predictions of the mantle melting model with observations made at different igneous provinces (Table I).

\subsection{Constraining the Volumetric Melt Flux Provided by Melting Anomalies and Its Temporal Variations}

If we assume that all melts generated within the mantle melting zone are emplaced as seismically observable igneous crust (McKenzie and Bickle, 1988), the excess of crustal thickness as compared to normal oceanic crust can be used to estimate the additional melt flux provided by a melting anomaly (e.g. Ito et al., 1997; Sallarès and Charvis, 2003). This value is called the volumetric melt flux for extra crustal production $\left(\mathrm{Q}_{\mathrm{v}}\right)$, and can be taken as a measure of the intensity of the melting anomaly. $Q_{v}$ can be calculated from crustal thickness measurements by integrating the excess crustal production along a given profile as follows:

$$
Q_{v}=U \int_{W}\left(h_{c}(x)-h\right) d x
$$

where $\mathrm{U}$ is the spreading rate, $\mathrm{W}$ is the width of the overthickened crustal segment, $\mathrm{x}$ is alongaxis distance, $h_{c}(x)$ is the crustal thickness measured at $\mathrm{x}$, and $\mathrm{h}$ represents normal crustal thickness.

It has to be noted, however, that $\mathrm{Q}_{\mathrm{v}}$ is a measure of the volume of melt "instantaneously" provided by a melting anomaly, so there are two conditions that must be accomplished to correctly estimate this value: 1 ) the $\mathrm{x}$-coordinate must be parallel to an isochron and, 2) the limits of integration, $\pm \mathrm{W} / 2$, must encompass the full overthickened crustal section between two contiguous oceanic basins. As we explained in section 2, WAS is probably the best method to precisely estimate the crustal geometry along a profile. In the case that the seismic profile is parallel to an isochron we can directly integrate the overthickening to calculate the volumetric melt flux provided by the melting anomaly at a 
given period of time. Unfortunately, this is rarely the case. In addition, the width of the overthickened crustal section is difficult to determine in the absence of seismic data.

A good opportunity to estimate both values is the case where melting anomalies interact with nearby oceanic spreading centers, which seems to be the case for at least 21 of the 30-50 identified present-day hotspots (Ito et al., 2003). Bathymetric and gravity data show that the along-axis width of the hotspot-affected region can be very large, especially for hotspots located just beneath or near the ridge axis, such as Iceland $(\sim 1500 \mathrm{~km}$, Ito et al., 1996) or Galápagos ( 1300 km, Ito et al., 1997). Long-lasting hotspot-ridge interactions generate volcanic edifices that form conjugate age-progressive tracks at both sides of the spreading center, for instance the V-shaped Cocos and Carnegie ridges in the GVP. By comparing the crustal geometry across different segments of the volcanic tracks it is possible to estimate the temporal variations of the melting anomaly intensity, which can in turn be interpreted in terms of the relative distance of the hotspot centre and the spreading axis (Sallarès and Charvis, 2003).

To a first order, the along-isochron Moho geometry can be estimated with a function decaying linearly from $H$ at $x=0$, to $h$ at $x= \pm W / 2$ and, under these circumstances, equation (1) can be then resolved analytically, and is reduced to:

$Q_{v}=\frac{(H-h) U W}{2}$

where $H$ is the maximum crustal thickness along the ridge-axis at a given period of time.

If we assume that temporal variations of the maximum potential intensity of the melting anomaly are primarily the result of variations in the distance between the melting anomaly centre and the spreading centre, $Q v$ must be maximum when the melting anomaly is ridgecentered, and asymptotic to zero for increasing hotspot-ridge distance. This tendency can be represented by the following function:

$Q_{v}=Q_{M} \exp (-\beta y)$

where $Q_{M}$ represents the maximum potential volumetric melt flux (i. e., for a ridge-centered anomaly), $y$ is the relative hotspot-ridge distance, and $\beta$ is a factor which determines the shape of the function. This function does not represent a rigorously based physical model but it is only an assumed idealization. Then, defining $\chi=Q_{v} / Q_{M}$, and comparing this value for two different profiles, we obtain from (3):

$y \log \chi_{0}=y_{0} \log \chi$ 
where $\chi\left(\chi_{0}\right)$ represents the relative intensity of the along-axis melting anomaly when it is located at $y\left(y_{0}\right)$ from the spreading centre.

It has been shown that $W$ depends primarily on $U$ at the time of crustal accretion (e.g. Ito and Lin, 1995). In the case that $U$ does not vary significantly over a given period of time, then we can approximate $\chi \sim(H-h) /\left(H_{M^{-}} h\right)$, and the relative distance between the hotspot centre and the spreading axis can be estimated based on (4).

In conclusion, if we know the maximum potential crustal thickness that can be generated by a melting anomaly, $\mathrm{H}_{\mathrm{M}}$, the hotspot-ridge distance, $\mathrm{y}_{0}$, and maximum along-axis crustal thickness, $\mathrm{H}_{0}$, at a given period of time, equation (4) provides a practical way to place first-order constraints on the relative intensity of the along-axis melting anomaly, $\chi_{1}$, and thus on the hotspot-ridge distance, $\mathrm{y}_{1}$, at any time we know the maximum along-axis crustal thickness, $\mathrm{H}_{1}$.

One example of this application is the GVP, where the comparison of crustal geometry along the present-day axis of the CNSC and across the Cocos, Carnegie, and Malpelo volcanic tracks (Figure 2a) has allowed constraining (1) the temporal variations of the volumetric melt flux, (2) the relative intensity of the Galápagos melting anomaly compared with the Hawaiian and Icelandic ones, (3) the relative motion of the CNSC with respect to the Galápagos hotspot, and (4) the tectonic evolution of the GVP during the last 20 m.y. (Sallarès and Charvis, 2003). Although these estimates are only approximate and depend heavily on several assumptions, the remarkable agreement between the results obtained and those of a number of previous studies using independent magnetic and GPS data (e.g. Barkhausen et al., 2001; Trenkamp et al., 2002) suggests that the approach works and is suitable for placing first-order constraints on the geodynamic evolution of the GVP. Although not all igneous provinces are well-suited to this type of study, the procedure can be probably extrapolated to other provinces characterized by the presence of age-progressive volcanic tracks, such as the Hawaiian-Emperor seamounts and island chain.

\subsection{Constraining The Parameters That Govern Mantle Melting}

Characterizing mantle melting anomalies based on crustal structure information is an approach that has received increasing attention during the last 15 years. The first attempt to quantitatively relate seismic crustal structure with mantle melting parameters was made by White and McKenzie (1989). Their approach consisted of relating variations in crustal thickness $(\mathrm{H})$ and $\mathrm{V}_{\mathrm{p}}$ with changes in mantle potential temperature for different factors of 
lithospheric stretching. They showed that if the temperature of the asthenosphere increases up to $1480^{\circ} \mathrm{C}$, some $200^{\circ} \mathrm{C}$ above normal, the percentage of $\mathrm{MgO}$ increases systematically from about $10 \%$ to $18 \%$. Thus, a systematic change in the $\mathrm{MgO}$ content of the melt with mantle temperature is predicted to cause systematic changes in $\mathrm{V}_{\mathrm{p}}$ and density of the igneous rocks formed on rifted margins. White et al. (1992) combined seismic observations with a rareEarth-element inversion technique to infer the amount of mantle melting generated as well as the depth interval over which it occurred. They concluded that the crustal structure and geochemical composition of oceanic and continental igneous provinces were the result of "decompression melting of abnormally hot mantle brought to the base of the lithosphere by plumes".

A second step in relating the seismic structure of the igneous crust with mantle melting parameters was made by Kelemen and Holbrook (1995). Its key contribution was to establish a function relating $\mathrm{Vp}$ in igneous rocks with the mean pressure of melting and melt fraction of the parental melt by multiple linear regression applied to the melt data of Kinzler and Grove (1992). The relationship obtained was tested by comparing its predictions with experimental results not included in the regression. Kelemen and Holbrook (1995) concluded that the highvelocity rocks of the East Coast Margin were the result of a thermal anomaly. Korenaga et al. (2002) followed the same approach to derive a more accurate relationship compiling an extensive set of high-quality experiments of mantle peridotites (e.g. Kinzler and Grove 1992; Hirose and Kushiro 1993; Kinzler 1997). They developed a 1-D steady-state mantle melting model including the effects of a pre-existing lithospheric lid and active mantle upwelling to compare predicted crustal thickness and lower crustal seismic velocity with seismic observations made at the southeastern Greenland margin. Their main conclusion was that the thick igneous crust with 6.9-7.0 km/s average lower-crustal $V_{p}$ results from active upwelling of normal-temperature mantle. Alternatively, they showed that the effect of major element heterogeneity in the mantle source can also be a key factor to account for the excess of magmatism.

An option which is not considered in the model of Korenaga et al. (2002) is the possible influence of deep damp melting between the dry and wet solidus for a volatile-bearing mantle. Damp melting has been suggested to account for a significant part of the total volume of melt, even if the melting rate is an order of magnitude lower than that of dry melting (Hirth and Kohlstedt, 1996; Braun et al., 2000), if it is coupled with vigorous upwelling at the base of the mantle melting zone ( $>70 \mathrm{~km}$ deep). Numerical models indicate that the viscosity increase associated with dehydration prevents buoyancy forces from contributing significantly to 
mantle upwelling above the dry solidus, indicating that active upwelling must be restricted only to the damp melting zone (Ito et al., 1999). Deep damp melting has been proposed to be the main source of magmatism, for instance, in GVP (Cushman et al., 2004) and Iceland (Maclennan et al., 2001).

Sallarès et al. (2005) modified the quantitative approach of Korenaga et al. (2002) to simulate mantle melting for a 2-D, steady-state, triangular melting regime resulting from mantle corner flow (e.g. Plank and Langmuir 1992). They incorporated the effect of deep damp melting (Hirth and Kohlstedt 1996; Braun et al. 2000). This model assumes perfect mixing and focussing of melts to generate oceanic crust, and restricts active upwelling to beneath the dry solidus (Ito et al., 1999). The average degree (pressure) of melting is calculated as the average degree (pressure) of melting of all the individual parcels of mantle pooled in the crust (Forsyth 1993; Plank et al. 1995), assuming a linear melting function as mantle wells up. The total volume of melts allows crustal thickness to be estimated, and the mean pressure and degree of melting are used to predict $\mathrm{V}_{\mathrm{p}}$ based on the multilinear regression of Korenaga et al. (2002) for mantle peridotites (Figure 3a).

In Figure 4, we illustrate the potential effect of the different mantle melting model parameters regards both $\mathrm{H}$ and mean lower crustal $\mathrm{V}_{\mathrm{p}}$, in order to provide a quantitative framework for comparison with seismic observations made at different igneous provinces (Table I). Key parameters used are the mantle upwelling ratio, $\chi$ (i.e. the ratio of mantle upwelling to seafloor spreading or plate velocity), the melt productivity within the dry and damp melting regions, $\Gamma_{\mathrm{d}}=10-20 \% / \mathrm{GPa}$ (McKenzie 1984; Langmuir et al. 1992) and $\Gamma_{\mathrm{w}} \sim 1$ $\% / \mathrm{GPa}$ (Braun et al., 2000), respectively, the thickness of the damp mantle melting zone, $\Delta \mathrm{z}=50-75 \mathrm{~km}$ (Hirth and Kohlstedt, 1996; Braun et al., 2000), the upwelling decay between the base and the top of the damp melting zone, $\alpha \sim 0.2$ (Ito et al., 1999), and the thickness of the pre-existing oceanic lithosphere, $b=0-70 \mathrm{~km}$.

For reference, we show in Figures $4 a$ and $4 b$ the predicted $H$ and $V_{p}$ versus mantle $T_{p}$ for a melting model with $\Gamma_{\mathrm{d}}=15 \% / \mathrm{GPa}, \Gamma_{\mathrm{w}}=1 \% / \mathrm{GPa}, \Delta \mathrm{z}=50 \mathrm{~km}, \alpha=0.2$, and $\mathrm{b}=0 \mathrm{~km}$. The different lines plotted correspond to different mantle upwelling ratios at the base of the mantle melting zone. The solid blue line corresponds to $\chi=0$, i.e., to passive dry mantle melting with no contribution from deeper damp melting. For a "normal mantle temperature" of $\mathrm{T}_{\mathrm{p}} \sim 1300^{\circ} \mathrm{C}$ the model predicts $\mathrm{H} \sim 7 \mathrm{~km}$ with $\mathrm{V}_{\mathrm{p}} \sim 7.1 \mathrm{~km} / \mathrm{s}$, in agreement with global compilations for normal oceanic crust (e.g. White et al., 1992). A $200^{\circ} \mathrm{C}$ increase in $\mathrm{T}_{\mathrm{p}}$ would produce a $\sim 30$ $\mathrm{km}$ thick crust with $\mathrm{V}_{\mathrm{p}} \sim 7.3 \mathrm{~km} / \mathrm{s}$, consistent with the calculations of White and McKenzie 
(1989). Incorporating progressively higher mantle upwelling ratios with identical melting parameters, results in consistently thicker crust and slightly higher $V_{p}$ for a given $T_{p}$. The latter is due to the fact that damp melting is extracted at high melting pressures and low melting fractions, resulting in lower $\mathrm{SiO}_{2}$ and higher $\mathrm{MgO}$ contents in mantle melts (Figure 3a). Thus, active upwelling $(\chi=20)$ of damp mantle source with a normal $\mathrm{T}_{\mathrm{p}}$ of only $1300^{\circ} \mathrm{C}$ could also account for a $23 \mathrm{~km}$ thick crust with $\mathrm{V}_{\mathrm{p}} \sim 7.15 \mathrm{~km} / \mathrm{s}$.

Figures $4 \mathrm{c}$ to $4 \mathrm{f}$ show the potential effect of $\Gamma_{\mathrm{d}}$ and $\Gamma_{\mathrm{w}}$ on the resulting crustal structure for $\chi=5$. Given that active upwelling is restricted to beneath the dry melting zone, the effect of $\Gamma_{d}$ variations in both $\mathrm{H}$ and $\mathrm{V}_{\mathrm{p}}$ is minor compared with those of $\Gamma_{\mathrm{w}}$. Thus, for a $\mathrm{T}_{\mathrm{p}}=1300{ }^{\circ} \mathrm{C}$, a $6 \%$ increase in $\Gamma_{\mathrm{d}}$ would result in a $\sim 3 \mathrm{~km}$ thicker crust, whereas an increase of only $1.5 \%$ in $\Gamma_{\mathrm{w}}$ would produce a $\sim 7 \mathrm{~km}$ thicker crust. The model also predicts an increment of $\mathrm{V}_{\mathrm{p}}$ with increasing melt productivity, which is more significant in the case of damp melting. The increment would be however of $\sim 0.1 \mathrm{~km} / \mathrm{s}$ at the most.

Another parameter with a notable effect on crustal structure is the thickness of the damp melting zone $(\Delta \mathrm{z})$. Figures $4 \mathrm{~g}$ and $4 \mathrm{~h}$ show that a $90 \mathrm{~km}$ thick damp melting zone (with $\chi=5$ and $\mathrm{T}_{\mathrm{p}} \sim 1300^{\circ} \mathrm{C}$ ) could generate a crustal thickening, $\Delta \mathrm{H} \sim 6 \mathrm{~km}$, with a $\mathrm{V}_{\mathrm{p}}$ increasing of 0.1 $\mathrm{km} / \mathrm{s}$.

In summary, it is interesting to note that it does not seem possible to find a plausible combination of $\mathrm{T}_{\mathrm{p}}, \chi, \Gamma_{\mathrm{d}}, \Gamma_{\mathrm{w}}$, and $\Delta \mathrm{z}$ to explain either (1) crustal roots (underplated bodies) with $\mathrm{V}_{\mathrm{p}}>7.5 \mathrm{~km} / \mathrm{s}$ that have been described from numerous igneous provinces (Table I), nor (2) the $\mathrm{H}-\mathrm{V}_{\mathrm{p}}$ anti-correlation found at other igneous provinces such as GVP, Kerguelen, or the North-Atlantic (Table I). It is therefore necessary to consider the effect of other mantle melting parameters when trying to explain these observations.

A common characteristic of igneous provinces showing high-velocity, underplated bodies is that most are thought to have originated in mid-plate settings (Table I). Thus, the presence of a lithospheric lid may play a role in determining the amount and properties of the melts generated. The lid will prevent shallow melting from occurring, resulting in limited amounts of higher pressure and lower fraction melting (higher $\mathrm{MgO}$ ) within the damp melting zone, and one would therefore expect a relative crustal overthickening with high-velocity cumulates (e.g. Kelemen and Holbrook, 1995). The effect of a pre-existing lithospheric lid of $35 \mathrm{~km}$ (with $\chi=5$ to enable direct comparison with the previous tests) is shown in Figures $4 \mathrm{i}$ and $4 \mathrm{j}$. Interestingly, the model predicts that in this case the occurrence of damp melting with a normal $\mathrm{T}_{\mathrm{p}} \sim 1300^{\circ} \mathrm{C}$ would result in a $\Delta \mathrm{H} \sim 5 \mathrm{~km}$, in remarkable agreement with seismic 
observations made at intra-plate oceanic provinces like Hawaii, Réunion, Marquesas or the Canary islands (Table I). However, no significant difference is visible in the predicted $\mathrm{V}_{\mathrm{p}}$ $(\sim 7.1 \mathrm{~km} / \mathrm{s})$. The reason of this lack of sensitivity on the predicted $V_{p}$ is that a thicker lid also increases $\mathrm{Na}_{2} \mathrm{O}$ and $\mathrm{FeO}$ contents. The result is to produce lower seismic velocity components, counterbalancing the effect of the $\mathrm{MgO}$ content increase. The $\mathrm{V}_{\mathrm{p}}(\mathrm{F}, \mathrm{P})$ relationship of Korenaga et al. (2002) takes into account this balance between the different compositional effects. For the same melting parameters, a $T_{p}>1375^{\circ} \mathrm{C}$ would be necessary to start generating melting beneath a thicker lithospheric lid of $b=70 \mathrm{~km}$. In this case, a moderate temperature increase of less than $100^{\circ} \mathrm{C}$ above normal $\left(\mathrm{T}_{\mathrm{p}} \leq 1400^{\circ} \mathrm{C}\right)$ would generate a $\Delta \mathrm{H}$ of $7-8 \mathrm{~km}$, with a significantly higher $\mathrm{V}_{\mathrm{p}}$ of $7.3 \mathrm{~km} / \mathrm{s}$. As stated above, still higher $\mathrm{V}_{\mathrm{p}}$ could be obtained with a thicker damp melting zone in combination with a slightly higher $\Gamma_{\mathrm{w}}$.

None of the melting parameters checked up to this point can, however, explain the lack of a positive $\mathrm{H}-\mathrm{V}_{\mathrm{p}}$ correlation found in several igneous provinces such as Galápagos, Kerguelen or the North-Atlantic (Table I). It has been previously suggested that an alternative explanation for this observation could be the presence of a compositional heterogeneity in the mantle source. As explained above, the $\mathrm{V}_{\mathrm{p}}(\mathrm{F}, \mathrm{P})$ relationship of figure $3 \mathrm{a}$ is only valid for mantle compositions similar to pyrolite, but too few melting experiments with source compositions different from pyrolite exist to develop a quantitative model including the effect of source heterogeneities. The only attempt to illustrate the potential effect of a major element heterogeneity in the mantle source was made by Korenaga et al. (2002). They developed a relationship between $\mathrm{V}_{\mathrm{p}}$ and the mean fraction and pressure of melting for a hypothetical source composed of $70 \%$ depleted pyrolitic mantle (Kinzler 1997) and $30 \%$ MORB (Hofmann 1988) (Figure 3b). The presence of a fertile component in the mantle source (i.e. the MORB) results in higher amounts of melting with lower $\mathrm{MgO}$ and considerable higher $\mathrm{FeO}$ content, for a given $\mathrm{T}_{\mathrm{p}}$, compared with a pyrolitic source. This effect is clearly observed in Figures $4 \mathrm{k}$ and 41 . For $\chi=5$ and a $T_{p}=1300^{\circ} \mathrm{C}$, a $18 \mathrm{~km}$-thick crust with $6.7-6.8 \mathrm{~km} / \mathrm{s}$ would be generated, in contrast with the $12 \mathrm{~km}$ and $7.1 \mathrm{~km} / \mathrm{s}$ that would result from pyrolite melting. In summary, the only plausible way of explaining the $\mathrm{H}-\mathrm{V}_{\mathrm{p}}$ anti-correlation seems to be the presence of a striking, major-element heterogeneity, such as eclogite derived from recycled oceanic lithosphere, in the mantle source. The possible influence of such a fertile anomaly in the mantle source to explain the geochemical and geophysical observations has been suggested for a number of hotspots including Iceland ( Korenaga and Kelemen, 2002; Foulger and Anderson, 2005; Foulger et al., 2005), Hawaii (Hauri, 1996; Sobolev et al., 2000), and 
Galápagos (Sallarès et al., 2005). What seems evident currently is that causes of hotspot magmatism are probably manifold. It appears clear to us that excess mantle temperature, even if coupled with deep damp melting, is not the only way of explaining the crustal structure observed at many igneous provinces. In some cases, as in Galapagos, observations are even contrary to what would be expected from melting of hotter-than-normal mantle.

However, it has to be noted that it is not easy to find a mechanism capable of explaining upwelling a Fe-rich mantle source. Subducted oceanic crust is denser than normal pyrolitic mantle above the bottom of the mantle transition zone (Ringwood \& Irifune 1988), so it will tend to lie at this level of neutral buoyancy unless it is sent back to the surface by a raising stream. Korenaga (2004) proposed sublithospheric convection driven by surface cooling as a plausible mechanism in the framework of continental breakup settings such as the NorthAtlantic Volcanic Province. We do not think, however, that the same mechanism can be applied to intraplate hotspots, so we prefer however to restrict our discussion to what can be deduced from the crustal-based approach.

Another process that could play a role in determining the seismic velocity of the igneous crust is the occurrence of subcrustal fractionation. When magmas fractionate, part of the high-velocity minerals (e.g., olivine, clinopiroxene) are segregated from the melts, and therefore the seismic velocities of the resulting igneous rocks could be lower than those expected for the primary, mantle-derived melt. Experiments on fractional crystallization modeling at high pressures (Korenaga et al., 2002) showed, however, that the effect of subcrustal fractionation is significant only for $\mathrm{V}_{\mathrm{p}}>7.5 \mathrm{~km} / \mathrm{s}$. In the case of normal $\mathrm{V}_{\mathrm{p}}<7.2$ $\mathrm{km} / \mathrm{s}$ this effect is negligible.

A promising interdisciplinary approach to infer the parameters controlling mantle melting consists of comparing observed geochemical signatures, physical properties, and Moho geometry of the igneous crust, with predictions based on experimental data with fluiddynamically consistent melting models for different source compositions. A first attempt was recently performed by Ito and Mahoney (2005). These authors developed a method that simulates fractional melting with thermodynamically consistent melting functions for a heterogeneous mantle composed of enriched and depleted mantle peridotite and pyroxenite. They demonstrated that variations in both mantle flow and lithospheric thickness between mid-ocean ridges and hotspots may lead to significant differences between the isotopic and trace-element characteristics of MORBs and OIBs, independent of any compositional differences between their respective mantle sources. 


\section{SUMMARY AND CONCLUSIONS}

In this work, we advocate an interdisciplinary approach to infer the parameters that govern mantle melting processes and the characteristics of the melting anomalies that comprise hotspot magmatism, based on crustal structure information obtained by means of seismic and gravity methods. Owing to the non-uniqueness of velocity and density modelling, comprehensive uncertainty analysis must be performed to quantitatively interpret the geophysical models as well as to use them to assess mantle melting processes. This linkage is crucial to relate the properties that can be measured in rocks with the underlying mantle properties and dynamics.

Combination of crustal seismology and gravity modelling enables the velocity and density structure and Moho geometry of the igneous crust to be constructed. We show with the example of the Cocos Ridge in the GVP that the crustal contribution to the gravity field can be more significant than usually thought. In this particular case, lateral variations of velocity-derived crustal density model account for most of the observed gravity and topography anomalies without need of calling for anomalous mantle densities. The remaining gravity and topography anomalies, if any, are under the uncertainty threshold of the method.

The example of the GVP is also used to show that the comparison of crustal thickness variations along age-progressive volcanic tracks can be used to approximate the temporal variations in the volumetric melt flux provided by a melting anomaly, enabling, in turn, to estimate variations on the relative distance between the spreading axis and the hotspot centre. The connection between the crustal structure of the igneous crust and the parameters governing mantle melting can be established based on models that simulate mantle melting and incorporate empirical relationships between the seismic velocity igneous rocks and the pressure and fraction of melting. We did several tests using a 2-D, steady state mantle melting model, and different combinations of mantle melting parameters to illustrate that the presence of water in the mantle source, a lithospheric lid limiting the extent of the mantle melting zone, and the composition of the source itself, can be as important as mantle temperature in controlling the amount of melt produced as well as the physical properties of the igneous crust. On one hand, we showed that the origin of $\sim 5 \mathrm{~km}$ thick, high-velocity underplated bodies frequently described at mid-plate settings (e.g. Hawaii, Réunion, Marquesas, Canary islands) could be explained by the presence of a pre-existing lithospheric lid on top of a damp (or fertile) melting anomaly with no significant thermal effect. On the other hand, we illustrated that the lack of a positive $\mathrm{H}-\mathrm{V}_{\mathrm{p}}$ correlation described in a number of igneous 
provinces originated in the vicinity of spreading centres (e.g., Galápagos, Kerguelen, Nazca, and the North-Atlantic) is difficult to reconcile with high temperature of a pyrolite mantle source. A likely explanation may be the presence of a major-element heterogeneity, such as eclogite derived from recycled oceanic lithosphere, in the mantle source.

Additional melting experiments with source compositions different from pyrolite are however required to improve quantitative assessment of the melting process including the effect of source heterogeneities. Considering predictions of the geochemical signatures of igneous rocks based on experimental data with fluid-dynamically consistent melting models constitutes a promising approach to improve our understanding on mantle melting and dynamics.

As a summary of the work performed, we list below the main steps of a suitable procedure to characterize mantle melting anomalies based on this crustal approach:

1) Tomography-based modelling of WAS data to estimate the seismic structure (Moho geometry, velocity field) of the crust;

2) Monte Carlo-type analysis of model parameter uncertainties;

3) Velocity-derived density modelling of gravity data to determine the crustal contribution to topography and the gravity field;

4) Estimation of mantle density and isostatic compensation depth corrected for the different crustal contributions (topography, Moho geometry, crustal density variations);

5) Propagation of seismic parameter uncertainties to predicted gravity and inferred mantle density;

6) Calculation of the volumetric flux of melting anomalies and its temporal variation by comparing the seismic structure along age-progressive volcanic tracks;

7) Inferring the relative significance of mantle melting parameters (temperature, upwelling ratio, damp melting, source composition) in the anomalous crustal production process on the basis of existing empirical relationships between bulk crustal velocity and the mean pressure and degree of melting.

8) If possible, comparing observed geochemical signatures and seismic structure of the igneous crust with predictions based on experimental data with fluid-dynamically consistent melting models for different source compositions. 


\section{ACKNOWLEDGEMENTS}

The work presented here benefited from fruitful discussions with Ph. Charvis and E.R. Flueh. Constructive reviews by Editors Gillian R. Foulger and Donna Purdy, as well as Tim Minshull and an anonymous reviewer helped to improve significantly the initial version of the manuscript. A significant part of the data processing and modelling that constitute the basis of the discussion was completed during part of the four-year visit of the authors to the Géosciences Azur Laboratory, Villefranche-sur-Mer, France. A. Calahorrano was supported by a grant from the Institute de Recherche pour le Développement (IRD) during that time. The WAS data used to construct the models were acquired during the German-French PAGANINI-1999 SALIERI-2001 surveys.

\section{REFERENCES}

Anderson, R. N., McKenzie, D., and Sclater, J.G., 1973, Gravity, bathymetry and convection in the Earth: Earth Planeary. Scence. Letters, v. 18, p. 391-407.

Barckhausen, U., Ranero, C.R., von Huene, R., Cande, S.C., and Roeser, H.A., 2001, Revised tectonic boundaries in the Cocos plate off Costa Rica: Implicatios for the segmentation of the convergent margin and for plate tectonic models: Journal of Geophysical Resarch, v. 106, no. 19, p. $207-$ 19,220 .

Barton, P.J., 1986, The relationship between seismic velocity and density in the continental crust - A useful constraint?: Geophysical Journal.of the Royal Astronomical Society, v. 87, p. 195-208.

Bickel, S.H., 1990, Velocity-depth ambiguity of reflection traveltimes: Geophysics, v. 55, p. 266-276.

Birch, F., 1961, The velocity of compressional waves in rocks to 10 kilobars, part 2: Journal of Geophysical. Research, v. 66, p. 2199-2224.

Bonatti, E., 1990, Not so hot "hot spots" in the oceanic mantle: Science, v. 250, no. 4977, p. 107-111.

Bratt, S.R., and Purdy, G.M., 1984, Structure and variability of oceanic crust in the flanks of the East Pacific Rise between $11^{\circ}$ and $13^{\circ}$ N: Journal of Geophysical Research, v. 89, p. 6111-6125.

Braun, M.G., Hirth, G., and Parmentier, E.M., 2000, The effects of deep damp melting on mantle flow and melt generation beneath mid-oceanic ridges: Earth and Planetary Science Letters, v. 176, p. 339-356.

Canales, J.P., Dañobeitia, J.J., and Watts, A.B, 2000, Wide-angle seismic constraints on the internal structure of Tenerife, Canary Islands: Journal of Volcanol ogy and Geothermal Research, v.103, p. $65-81$. 
Canales, J.P., Ito, G., Detrick, R.S., and Sinton, J., 2002, Crustal thickness along the western Galápagos Spreading Center and compensation of the Galápagos Swell: Earth and Planetary Science Letters, v. 203, p. 311-327.

Caress, D.W., Nutt, M.K., Detrick, R.S., and Mutter, J.C., 1995, Seismic imaging of hotspot-related crustal underplating beneath the Marquesas islands: Nature, v. 373, p. 600-603.

Carlson, R.L. and Herrick, C.N., 1990, Densities and porosities in the oceanic crust and their variations with depth and age: Journal of Geophysical Research, v. 95, p. 9153-9170.

Charvis, Ph., and Operto, S., Structure of the Cretaceous Kerguelen Volcanic Province (southern Indian Ocean) from wide-angle seismic data: Journal of Geodynamics, v. 28, p. 51-71.

Charvis, Ph., Laesanpura, A., Gallart, J., Hirn, A., Lépine, J.-C., de Voogd, B., Hello, Y., Pontoise, B., and Minshull, T.A., 1999, Spatial distribution of hotspot material added to the lithosphere under La Réunion, from wide-angle seismic data: Journal of Geophysical Research, v. 104, p. 28752893.

Christensen, N.I., and Mooney, W.D., 1995, Seismic velocity structure and composition of the continental crust: A global view: Journal of Geophysical Research, v. 100, p. 9761-9788.

Coffin, M.F., and Eldholm, O., 1994, Large Igneous Provinces: Crustal structure, dimensions \& external consequences: Reviews of Geophysics, v. 32, p. 1-36.

Cushman, B.J., Sinton, J.M., Ito, G., and Dixon, J.E., 2004, Glass compositions, plume-ridge interaction, and hydrous melting along the Galápagos Spreading Center, $90^{\circ} 30^{\prime} \mathrm{W}$ to $98^{\circ} \mathrm{W}$ : Geochemistry, Geophysics, Geosystems, v. 5, Q089E17, doi:10.1029/2004GC000709.

Darbyshire, F.A., Bjarnason, I. Th., White, R.S., and Flovenz, O.G., 1998, Crustal structure above the Iceland mantle plume imaged by the ICEMELT refraction profile: Geophysical Journal International, v. 135, p. 1131-1149.

Darbyshire, F.A., White, R. S., and Priestley, K. F., 2000, Structure of the crust and uppermost mantle of Iceland from a combined seismic and gravity study: Earth and Planetry Science Letters, v. 181, p. 409-428.

Detrick, R.S., Collins, J., Stephen, R., and Swift, S., 1994, In situ evidence for the nature of the Layer 2 / 3 boundary in oceanic crust: Nature, v. 370, p. 288-290.

Falloon, T., 2006, On the lack of temperature differences between hot MORB and Hawaiian basalt, In: in Foulger, G.R.,and Purdy, D.. eds., The Origins of Melting Anomalies: Plumes, Plates, and Planetary Processes, Geological Society of America Special Paper. \#\#\#, p. 000-000 (this volume).

Forsyth, D.W., 1993, Crustal thickness and the average depth and degree of melting in fractional melting models of passive flow beneath mid-ocean ridges: Jounal of Geophysical Research, v. 98, p. $16073-16079$.

Foulger, G.R., and Anderson, D.L., 2005, A cool model for the Iceland hotspot: Journal of Volcanology and Geothermal Research, v. 141, p. 1-22. 
Foulger, G. R., Natland, J. H., andAnderson, D. L., 2005, A source for Icelandic magmas in remelted Iapetus crust: Journal of Volcanology and Geothermal Research, v. 141, p. 23-44.

Green, D. H., and Falloon, T. J., 2005, Primary magmas at mid-ocean ridges, "hot spots" and other intraplate settings; constraints on mantle potential temperature, in Plates, Plumes \& Paradigms, edited by G. R. Foulger, J.H. Natland, D.C. Presnall and D.L. Anderson, pp. 217-248, Geological Society of America.

Green, D. H., Falloon, T. J., Eggins, S. M., and Yaxley, G. M., 2001, Primary magmas and mantle temperatures: European Journal of Mineralogy, v. 13, p. 437-451.

Grevemeyer, I., Flueh , E.R., Reichert, C., Bialas, J., Kläschen, D., and Kopp, C., 2001, Crustal architecture and deep structure of the Ninetyeast Ridge hotspot trail from active-source ocean bottom seismology: Geophysical Journal International, v. 144, p. 414-431.

Hampel, A., Kukowski, N., Bialas, J., Huebscher, C., and Heinbockel, R., 2004, Ridge subduction at an erosive margin - the collision zone of the Nazca Ridge in southern Peru: Journal of Geophysical Research, v. 109, B02101, doi:10.1029/2003JB002593.

Hauri, E.H., 1996, Major element variability in the Hawaiian mantle plume: Nature, v. 382, p. 415-419.

Hirose, K., and Kushiro, I., 1993, Partial melting of dry peridotites at high pressures: Determination of composition of melts segregated from peridotite using aggregates of diamond: Earth and Planetary Science Letters, v. 114, p. 477-489.

Hirth, G. and, Kohlstedt, D.L., 1996, Water in the oceanic upper mantle: implications for rheology, melt extraction and the evolution of the lithosphere: Earth and Planetary Science Letters, v. 144, p. 93-108.

Hobro, J., Singh, S.C., and Minshull, T.A., 2003, Three-dimensional tomographic inversion of combined reflection and refraction seismic traveltime data: Geophysical Journal International, v. 152 , p. $79-93$.

Hofmann, A.W., 1988, Chemical differentiation of the Earth: the relationship between mantle, continental crust and oceanic crust: Earth and Planetary Science Letters, v. 90, p. 297-314.

Ito, G., and Lin, J., 1995, Mantle temperature anomalies along the present and paleoaxes of the Galápagos Spreading Center as inferred from gravity analyses: Journal of Geophysical Research, v. 100, p. 3733-3745.

Ito, G., Lin, J., and Gable, C.W., 1996, Dynamics of mantle flow and melting at a ridge-centered hotspot: Iceland and the Mid-Atlantic Ridge: Earth and Planetary Science Letters, v. 144, p. 5374.

Ito, G., Lin, J., and Gable, C.W., 1997, Interaction of mantle plumes and migrating mid-ocean ridges: Implications for the Galápagos plume-ridge system: Journal of Geophysical Research, v. 102, p. 15403-15417. 
Ito, G., Shen, Y., Hirth, G., and Wolfe, C.J., 1999, Mantle flow, melting and dehydration of the Iceland mantle plume: Earth and Planetary Science Letters, v. 165, p. 81-96.

Ito, G., Lin, J., and Graham, D., 2003, Observational and theoretical studies of the dynamics of mantle plume-mid-ocean ridge interaction: Reviews of Geophysics, v. 41, no. 4, 1017, doi:10.1029/2002RG000117.

Ito, G., and Mahoney, J.J., 2005, Flow and melting of a heterogeneous mantle: 1. Method and importance to the geochemistry of ocean island and mid-ocean ridge basalts: Earth and Planetary Science Letters, v. 230, p. 29-46.

Kelemen, P.B., and Holbrook, W.S., 1995, Origin of thick, high-velocity igneous crust along the U.S. East Coast margin: Journal of Geophysical Research, v. 100, p. 10077-10094.

Kinzler, R.J., 1997, Melting of mantle peridotite at pressures approaching the spinel to garnet transition: Application to mid-ocean ridge basalt petrogenesis: Journal of Geophysical Research, v. 102, p. 852-874.

Kinzler, R.J., and Grove, T.L., 1992, Primary magmas of mid-ocean ridge basalts, 2, applications: Journal of Geophysical Research, v. 97, p. 6907-6926.

Korenaga, J., Holbrook, W.S., Kent, G.M., Kelemen, P.B., Detrick, R.S., Larsen, H.-C., Hopper, J.R., and Dahl-Jensen, T., 2000, Crustal structure of the southeast Greenland margin from joint refraction and reflection seismic tomography: Journal of Geophysical Research, v. 105, p. 21591-21614.

Korenaga, J., Holbrook, W.S., Detrick, R.S., and Kelemen, P.B., 2001, Gravity anomalies and crustal structure at the southeast Greenland margin: Journal of Geophysical Research, v. 106, p. 88538870 .

Korenaga, J., Kelemen, P.B., and Holbrook, W.S., 2002, Methods for resolving the origin of large igneous provinces from crustal seismology: Journal of Geophysical Research, v. 107, no. B9, 2178, doi:10.1029/2001JB001030.

Korenaga, J., 2004, Origin of the Iceland hotspot and the North Atlantic Igneous Province: http://www.mantleplumes.org.

Langmuir, C.H., Klein, E.M. and Plank, T., 1992, Petrological systematics of mid-ocean ridge basalts: Constraints on melt generation beneath mid-oceanic ridges, in Phipps-Morgan, J., Blackman, D.K., and Sinton, J.M., eds., Mantle flow and melt generation at Mid-Oceanic ridges, Geophysical Monograph Service, v. 71, p. 183-280, Americal Geophysical Union.

Maclennan, J., McKenzie, D., and Gronvold, K., 2001, Plume-driven upwelling under central Iceland: Earth and Planetary Science Letters, v. 194, p. 67-82.

McKenzie, D, 1984, The generation and compaction of partially molten rock: Journal of Petrology, v. 25, p. $713-765$.

McKenzie, D., and Bickle, M.J., 1988, The volume and composition of melt generated by extension of the lithosphere: Journal of Petrology, v. 29, p. 625-679. 
McNutt, M.K., and Bonneville, A., 2000, A shallow, chemical origin, for the Marquesas swell: Geochemistry, Geophysics, Geosystems, v. 1, no. 1999GC000028.

Miura, S., Suyehiro, K., Shinohara, M., Takahashi, N., Araki, E., and Taira, A., 2004, Seismological structure and implications of collision between the Ontong Java Plateau and Solomon Island Arc from ocean bottom seismometer-airgun data: Tectonophysics, v. 389, p. 191- 220.

Montelli, R., Nolet, G., Dahlen, F.A., Masters, G., Engdahl, E.R., Hung, S.-H., 2004, Finite-Frequency Tomography Reveals a Variety of Plumes in the Mantle: Science, v. 303, no. 5656, p. $338-$ 343, doi: 10.1126/science.1092485.

Morgan, W.J., 1971, Convection plumes in the lower mantle: Nature, v. 230, p. 42-43.

Mutter, C.Z., and Mutter, J.C., 1993, Variations in thickness of Layer 3 dominate oceanic crustal structure: Earth and Planetary Science Letters, v. 117, p. 295-317.

Nielsen, L., and Jacobsen, B. H., 2000, Integrated gravity and wide-angle seismic inversion for 2-D crustal modelling: Geophysical Journal International, v. 140, p. 222-232.

Oxburgh, E.R. and Parmentier, E.M., 1977, Compositional and density stratification in oceanic lithosphere - causes and consequences: Journal of the Geological Society of London, v. 133, p. $343-355$.

Phipps Morgan, J., Morgan, W.J., and Price, E., 1995, Hotspot melting generates both hotspot volcanism and a hotspot swell?: Journal of Geophysical Research, v. 100, p. 8045-8062.

Phipps Morgan, J., and Morgan, W.J., 1999, Two-stage melting and the geochemical evolution of the mantle: A recipe for mantle plum-pudding: Earth and Planetary Science Letters, v. 170, p. 215239.

Plank, T., and Langmuir, C.H., 1992, Effects of melting regime on the composition of the oceanic crust: Journal of Geophysical Research, v. 97, p. 19749-19770.

Plank, T., Spiegelman, M., Langmuir, C.H., and Forsyth, D.H., 1995, The meaning of "mean F": Clarifying the mean extent of melting at ocean ridges: Journal of Geophysical Research, v. 100, p. 15045-15052.

Ringwood, A.E., and Irifune, T., 1988, Nature of the $650-\mathrm{km}$ seismic discontinuity - implications for mantle dynamics and differentiation: Nature, v. 331, p. 131-136.

Sallarès, V., and Charvis, Ph., 2003, Crustal thickness constraints on the geodynamic evolution of the Galápagos volcanic province: Earth and Planetary Science Letters, v. 214, no. 3-4, p. 545559.

Sallarès, V., Charvis, Ph., Flueh, E. R. and Bialas, J., 2003, Seismic structure of Cocos and Malpelo ridges and implications for hotspot-ridge interaction: Journal of Geophysical Research, v. 108, no. 2564, doi: 10.1029/2003JB002431. 
Sallarès, V., Charvis, Ph., Flueh, E.R., Bialas, J., and the SALIERI Scientific Party, 2005, Seismic structure of the Carnegie ridge and the nature of the Galápagos hotspot: Geophysical Journal International, v. 161, no. 3, p. 763-788, doi: 10.1111/ j.1365-246 X.2005.02592.x.

Schilling, J.-G., Zajac, M., Evans, R., Johnson, T., White, W., Devine, J.C., and Kingsley, R., 1983, Petrological and geochemical variations along the Mid-Atlantic ridge from $29^{\circ} \mathrm{N}$ to $73^{\circ} \mathrm{N}$ : American Journal of Science, v. 283, p. 510-586.

Sobolev, A., Hofmann, A.W., Nikogosian, I.K., 2000, Recycled oceanic crust observed in "ghost plagioclase" within the source of the Mauna Loa lavas: Nature, v. 404, p. 986-990.

Tarantola, A., 1987, Inverse problem theory: Methods for data fitting and model parameter estimation, 613 pp., Elsevier Science Ltd.

Trenkamp, R., Kellogg, J.N., Freymueller, J.T., and Mora, H.P., 2002, Wide plate margin deformation, southern Central America and northwestern South America, CASA GPS observations: Journal of South American Sciences, v. 15, p. 157-171.

Watts, A. B., and ten Brink, U.S., 1989, Crustal structure, flexure, and subsidence history of the Hawaiian Islands: Journal of Geophysical Research, v. 94, p. 10473- 10500.

Watts, A.B., Pierce, C., Collier, J., Dalwood, R., Canales, J.P., and Henstock, T.J., 1997, A seismic study of lithospheric flexure in the vicinity of Tenerife, Canary Islands: Earth and Plaetary Science Letters, v. 146, p. 431-447.

White, R.S., and McKenzie, D., 1989, Magmatism at rift zones: The generation of volcanic continental margins and flood basalts: Journal of Geophysical Research, v. 94, p. 7685-7794.

White, R.S., McKenzie, D., and O’Nions, R.K., 1992, Oceanic crustal thickness from seismic measurements and Rare Earth Element inversions: Journal of Geophysical Research, v. 97, p. 19683-19715.

Wilson, J.T., 1963, A possible origin of the Hawaiian Islands: Canadian Journal of Physics, v. 41, p. 863-870.

Ye, S., Canales, J.P., Rihm, R., Danobeitia, J.J., and Gallart, J., 1999, A crustal transect through the northern and northeastern part of the volcanic edifice of Gran Canaria, Canary Islands: Journal of Geodynamics, v. 28, p. $3-26$.

Zelt, C.A., and Barton, P.J., 1998, 3D seismic refraction tomography: A comparison of two methods applied to data from the Faeroe Basin; Journal of Geophysical Research, v. 103, p. 7187-7210.

Zhao, D., 2001, Seismic structure and origin of hotspots and mantle plumes: Earth and Planetary Science Letters, v. 192, p. 251-265. 


\section{TABLE CAPTIONS}

Table I.- Table indicating location, estimated total crustal thickness (T.C.T.), mean Layer 3 velocity, ratio of Layer 2 versus total crustal thickness (L2/T.C.T.), thickness of the underplated body at the base of the igneous crust (U.P. thickness), seismic velocity of the underplated body (U.P. velocity), and emplacement setting, for a number of igneous provinces. 


\section{FIGURE CAPTIONS}

Figure 1.- Map showing the large igneous provinces that have been recognized around the Atlantic ocean (red areas). Yellow circles indicate the location of currently active hotspots (modified from Korenaga, 2004).

Figure 2.- (a) Bathymetric map of the Galápagos Volcanic Province (GVP) in the easternmost Pacific ocean. Shaded areas indicate shallower seafloor than predicted based on plate cooling models. The location of the seismic profile across the Cocos Ridge is shown in red. CNSC: Cocos-Nazca Spreading Center; EPR: East Pacific Rise. (b) Example of a seismic record section registered at an Ocean Bottom Seismometer (OBS) during the SALIERI-2001 cruise in the GVP. Pg and PmP denote seismic phases refracted within the crust and reflected at the crust-mantle boundary, respectively. (c) Seismic tomography model obtained across the Cocos Ridge in the GVP. The velocity model and Moho geometry correspond to the average of 100 Monte Carlo inversions (see text for details). Open circles indicate OBS locations. (d) and (e) Density models along the profile shown in Figure 2c. Model I has the Moho geometry obtained from seismic tomography (Figure 2c) and a uniform crustal density of 2,900 kg/m ${ }^{3}$. Model II has the same Moho geometry as Model I, but density has been derived from seismic velocity (Figure 2c) using the relationships of Carlson and Herrick (1990) and Birch (1961) for oceanic Layers 2 and 3. (f) and (g) Residual gravity anomaly (RGA), which is the difference between observed Free-Air gravity anomaly and calculated gravity anomaly for Models I and II. White band in panel (g) shows the gravity anomaly uncertainty inferred from the Monte Carlo analysis. (h) and (i) Mantle density anomaly (MDA) corresponding to Models I and II, inferred from topography compensation analysis. The calculation has been repeated for different values of the compensation depth, $Z=50 \mathrm{~km}$ (red line), $100 \mathrm{~km}$ (orange line), and $200 \mathrm{~km}$ (blue line). In panel (i), white bands between the coloured lines denote mantle density uncertainty inferred from the Monte Carlo analysis for each compensation depth.

Figure 3.- (a) Contours of predicted seismic velocity (in $\mathrm{km} / \mathrm{s}$ ) for mantle melts as a function of their mean pressure $(\mathrm{P})$ and fraction $(\mathrm{F})$ of melting using the multiple linear regression of data from melting experiments of mantle peridotites. (b) Same as (a), but 
for a hypotetical fertile mantle melting composed of $70 \%$ depleted pyrolitic mantle and $30 \%$ MORB (Korenaga et al. 2002).

Figure 4.- Diagrams of predicted crustal thickness (left) and mean Layer 3 velocity (right) versus $T_{p}$ of the mantle source using the 2-D, steady state, mantle melting model of Sallarès et al. (2005) and the $\mathrm{V}_{\mathrm{p}}(\mathrm{F}, \mathrm{P})$ relationship of Korenaga et al. (2002) for mantle peridotite (Figure 3a). Reference model parameters are $\Gamma_{d}=15 \% / \mathrm{GPa}, \Gamma_{\mathrm{w}}=1 \% / \mathrm{GPa}$, $\chi=10, \Delta \mathrm{z}=50 \mathrm{~km}, \alpha=0.2$, and $\mathrm{b}=0 \mathrm{~km}$ (see text for definition). (a) and (b) Effect of increasing mantle upwelling ratio at the base of the mantle melting zone, $\chi=0$ (blue line, dry melting only), $\chi=5$ (solid black line), $\chi=10$ (dashed line), $\chi=20$ (dotted line). (c) and (d) Effect of increasing melt productivity in the dry melting zone, $\Gamma_{\mathrm{d}}=15 \% / \mathrm{GPa}$ (solid), $\Gamma_{\mathrm{d}}=18 \% / \mathrm{GPa}$ (dashed), $\Gamma_{\mathrm{d}}=21 \% / \mathrm{GPa}$ (dotted). (e) and (f) Effect of increasing melt productivity in the damp melting zone, $\Gamma_{\mathrm{w}}=1 \% / \mathrm{GPa}$ (solid), $\Gamma_{\mathrm{w}}=2.5 \% / \mathrm{GPa}$ (dashed), $\Gamma_{\mathrm{w}}=5 \% / \mathrm{GPa}$ (dotted). (g) and (h) Effect of increasing thickness of the damp melting zone, $\Delta \mathrm{z}=50 \mathrm{~km}$ (solid), $\Delta \mathrm{z}=70 \mathrm{~km}$ (dashed), $\Delta \mathrm{z}=90 \mathrm{~km}$ (dotted). (i) and (j) Effect of increasing thickness of the pre-existing lithospheric lid, $b=0 \mathrm{~km}$ (solid), $b=35$ $\mathrm{km}$ (dashed), b=70 km (dotted). (k) and (1) Effect of mantle souce heterogeneity. Solid lines have been calculated with reference model parameters and the $\mathrm{V}_{\mathrm{p}}(\mathrm{F}, \mathrm{P})$ relationship of Figure 3a, and dashed line for a hypotetical fertile mantle melting composed of $70 \%$ depleted pyrolitic mantle and $30 \%$ MORB (Figure 3b). 


\begin{tabular}{|c|c|c|c|c|c|c|c|}
\hline $\begin{array}{l}\text { Igneous } \\
\text { Province } \\
\end{array}$ & Location & T.C.T. & $\begin{array}{c}\text { Mean L3 } \\
\text { Velocity } \\
\end{array}$ & $\begin{array}{c}\text { L2/ } \\
\text { T.C.T. }\end{array}$ & $\begin{array}{c}\text { U.P. } \\
\text { Thickness } \\
\end{array}$ & $\begin{array}{c}\text { U.P. } \\
\text { Velocity }\end{array}$ & Emplaced \\
\hline $\begin{array}{l}\text { Hawai- } \\
\text { Emperor }\end{array}$ & Hawai $^{(1)}$ & $15 \mathrm{~km}$ & $6.9 \mathrm{~km} / \mathrm{s}$ & $45 \%$ & $3 \mathrm{~km}$ & $7.7 \mathrm{~km} / \mathrm{s}$ & Off-ridge \\
\hline Canary & $\begin{array}{l}\text { Gran Canaria }^{(2)} \\
\text { Tenerife }^{(3,4)}\end{array}$ & $\begin{array}{l}20 \mathrm{~km} \\
13 \mathrm{~km}\end{array}$ & $\begin{array}{l}6.9 \mathrm{~km} / \mathrm{s} \\
6.9 \mathrm{~km} / \mathrm{s}\end{array}$ & $\begin{array}{l}50 \% \\
60 \% \\
\end{array}$ & $\begin{array}{c}5 \mathrm{~km} \\
i\end{array}$ & $\begin{array}{c}7.5 \mathrm{~km} / \mathrm{s} \\
>7.3 \mathrm{~km} / \mathrm{s}\end{array}$ & $\begin{array}{l}\text { Off-ridge } \\
\text { Off-ridge }\end{array}$ \\
\hline Marquesas & Marquesas Isl. $^{(5)}$ & $11 \mathrm{~km}$ & $7.0 \mathrm{~km} / \mathrm{s}$ & $50 \%$ & $6 \mathrm{~km}$ & $7.7 \mathrm{~km} / \mathrm{s}$ & Off-ridge \\
\hline Réunion & Réunion Island $^{(6)}$ & $13 \mathrm{~km}$ & $6.8 \mathrm{~km} / \mathrm{s}$ & $50 \%$ & $3 \mathrm{~km}$ & $7.5 \mathrm{~km} / \mathrm{s}$ & Off-ridge \\
\hline Kerguelen & $\begin{array}{l}\text { Ninetyeast R. }{ }^{(7)} \\
\text { N Kerguelen }^{(8)}\end{array}$ & $\begin{array}{l}18 \mathrm{~km} \\
24 \mathrm{~km} \\
\end{array}$ & $\begin{array}{l}7.0 \mathrm{~km} / \mathrm{s} \\
7.0 \mathrm{~km} / \mathrm{s}\end{array}$ & $\begin{array}{l}23 \% \\
26 \% \\
\end{array}$ & $\begin{array}{c}5 \mathrm{~km} \\
- \\
\end{array}$ & $\begin{array}{c}7.5 \mathrm{~km} / \mathrm{s} \\
-\end{array}$ & $\begin{array}{l}\text { Off-ridge } \\
\text { On-ridge }\end{array}$ \\
\hline $\begin{array}{l}\text { Ontong- } \\
\text { Java P }\end{array}$ & Solomon Islands ${ }^{(9)}$ & $34 \mathrm{~km}$ & $7.1 \mathrm{~km} / \mathrm{s}$ & $27 \%$ & - & - & On-ridge \\
\hline $\begin{array}{l}\text { North- } \\
\text { Atlantic VP }\end{array}$ & $\begin{array}{l}\text { Central Iceland }^{(10)} \\
\text { SE Greenland }^{(11)}\end{array}$ & $\begin{array}{l}35 \mathrm{~km} \\
27 \mathrm{~km}\end{array}$ & $\begin{array}{l}7.0 \mathrm{~km} / \mathrm{s} \\
6.9 \mathrm{~km} / \mathrm{s}\end{array}$ & $\begin{array}{l}21 \% \\
26 \%\end{array}$ & $\begin{array}{l}- \\
-\end{array}$ & $\begin{array}{l}- \\
-\end{array}$ & $\begin{array}{l}\text { On-ridge } \\
\text { On-ridge }\end{array}$ \\
\hline $\begin{array}{l}\text { Galápagos } \\
\text { VP }\end{array}$ & $\begin{array}{l}\text { Carnegie R. }^{(12)} \\
\text { Cocos R. }{ }^{(13)} \\
\text { Malpelo R. }{ }^{(13)}\end{array}$ & $\begin{array}{l}19 \mathrm{~km} \\
17 \mathrm{~km} \\
19 \mathrm{~km} \\
\end{array}$ & $\begin{array}{l}6.85 \mathrm{~km} / \mathrm{s} \\
6.95 \mathrm{~km} / \mathrm{s} \\
6.85 \mathrm{~km} / \mathrm{s} \\
\end{array}$ & $\begin{array}{l}26 \% \\
25 \% \\
25 \% \\
\end{array}$ & $\begin{array}{l}- \\
- \\
-\end{array}$ & $\begin{array}{l}- \\
- \\
-\end{array}$ & $\begin{array}{l}\text { On-ridge } \\
\text { On-ridge } \\
\text { On-ridge }\end{array}$ \\
\hline Nazca R. & East Nazca R. ${ }^{(14)}$ & $17 \mathrm{~km}$ & $7.0 \mathrm{~km} / \mathrm{s}$ & $27 \%$ & - & - & On-ridge \\
\hline
\end{tabular}

(1) Watts and Ten Brink, 1989; (2) Ye et al., 1999; (3) Watts et al., 1997; (4) Canales et al., 2000 ; (5) Caress et al., 1995; (6) Charvis et al., 1999; (7) Grevemeyer et al., 2001; (8) Charvis and Operto, 1999; (9) Miura et al., 2004; (10) Darbyshire et al., 1998; (11) Korenaga et al., 2000, (12) Sallarès et al., 2003, (13) Sallarès et al., 2005, (14) Hampel et al., 2004.

Table I 


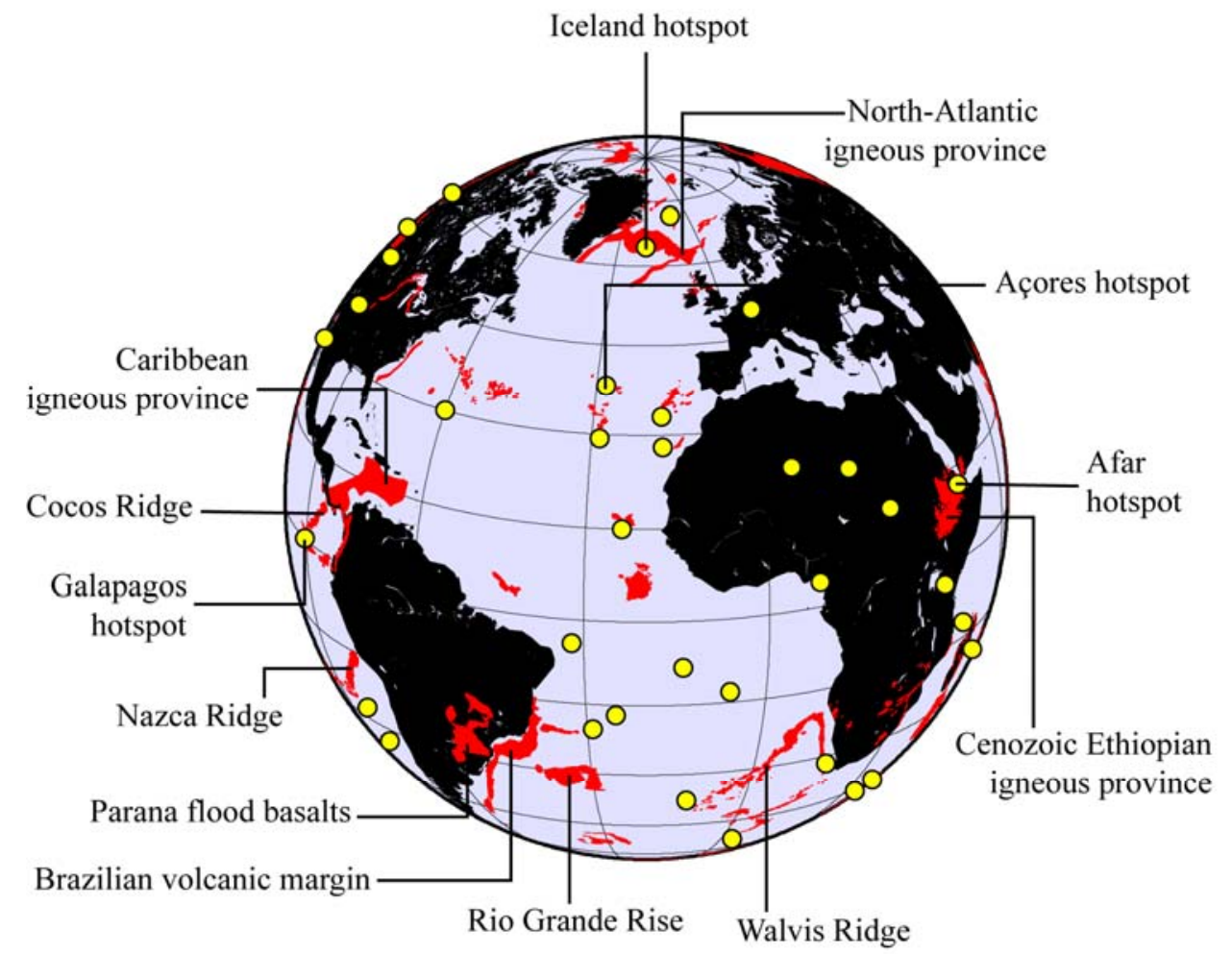

Figure 1 
a)

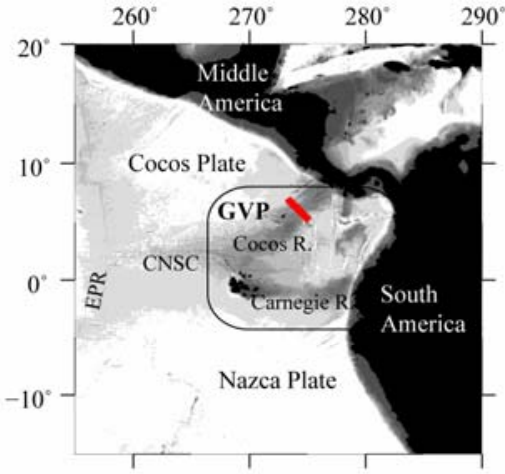

b)

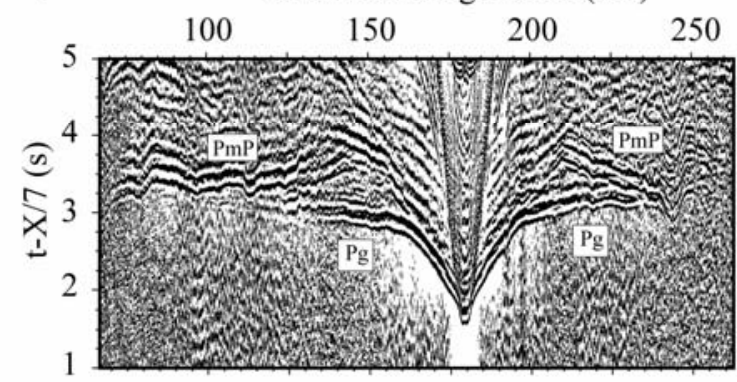

d)

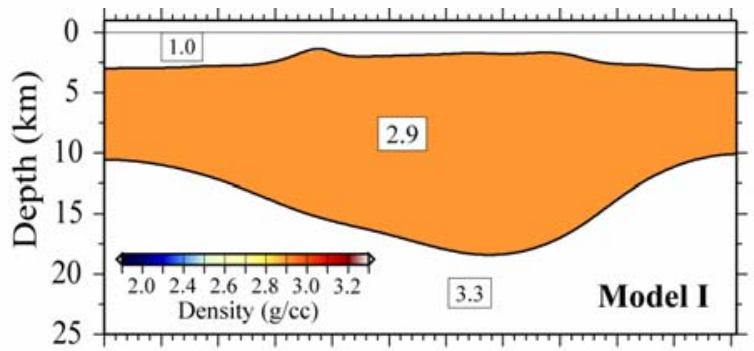

f)

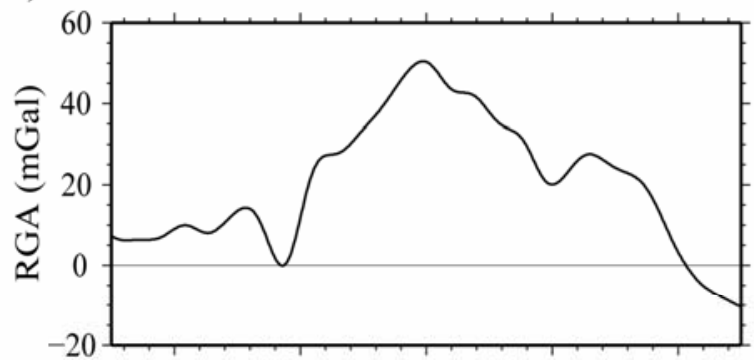

h)

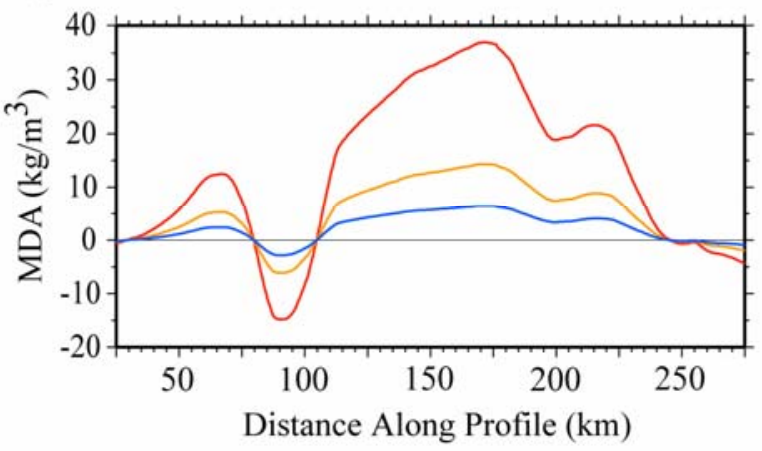

c)

Distance Along Profile (km)

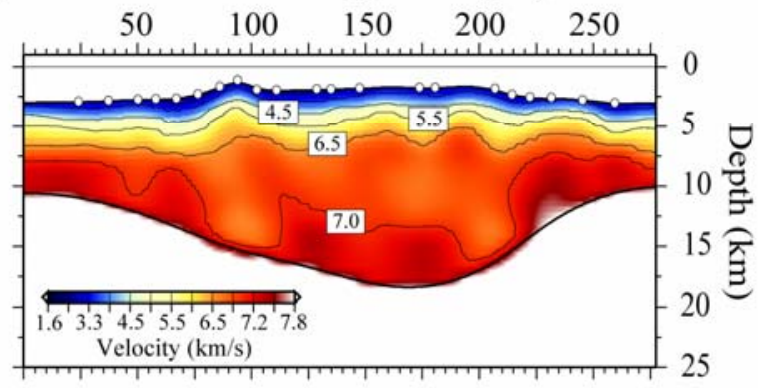

e)

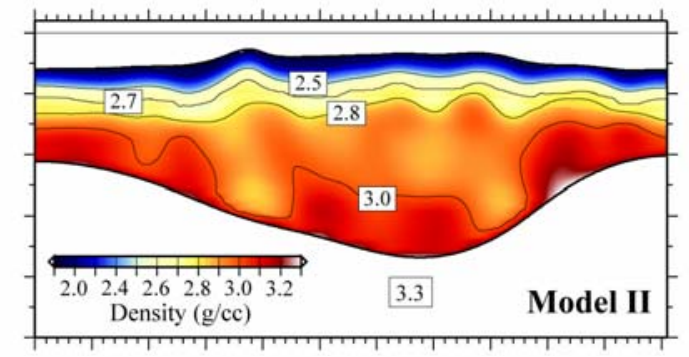

g)

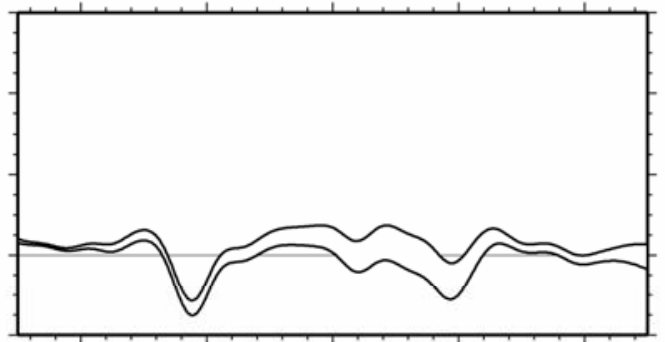

i)

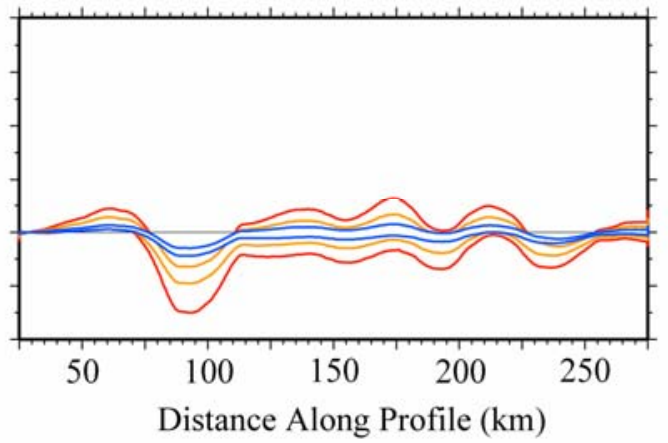

Figure 2 
a)

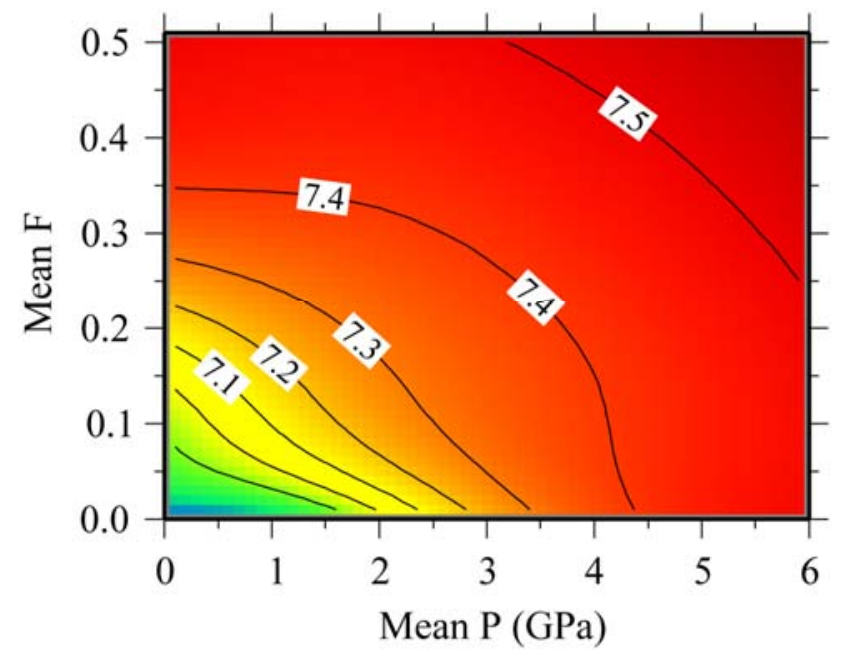

b)

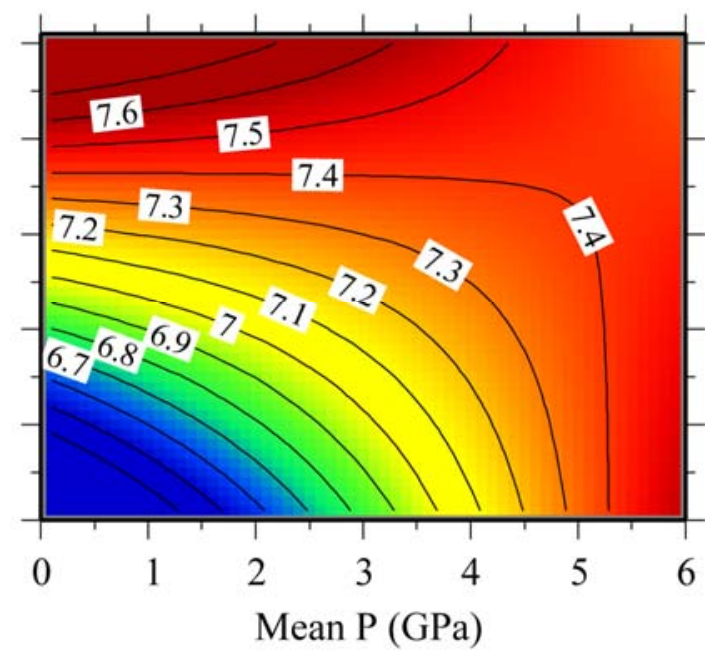

Figure 3 
Crustal Thickness (km)
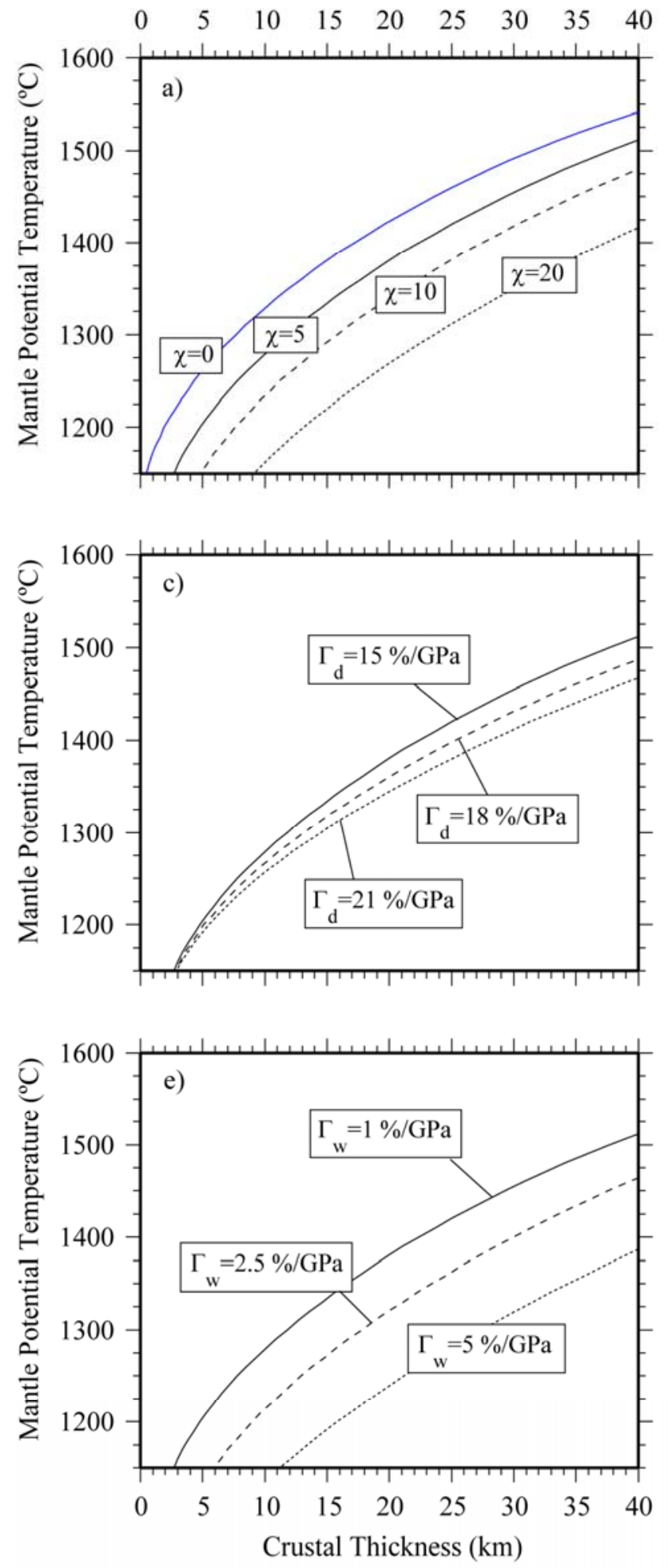

Mean Layer 3 Velocity $(\mathrm{km} / \mathrm{s})$
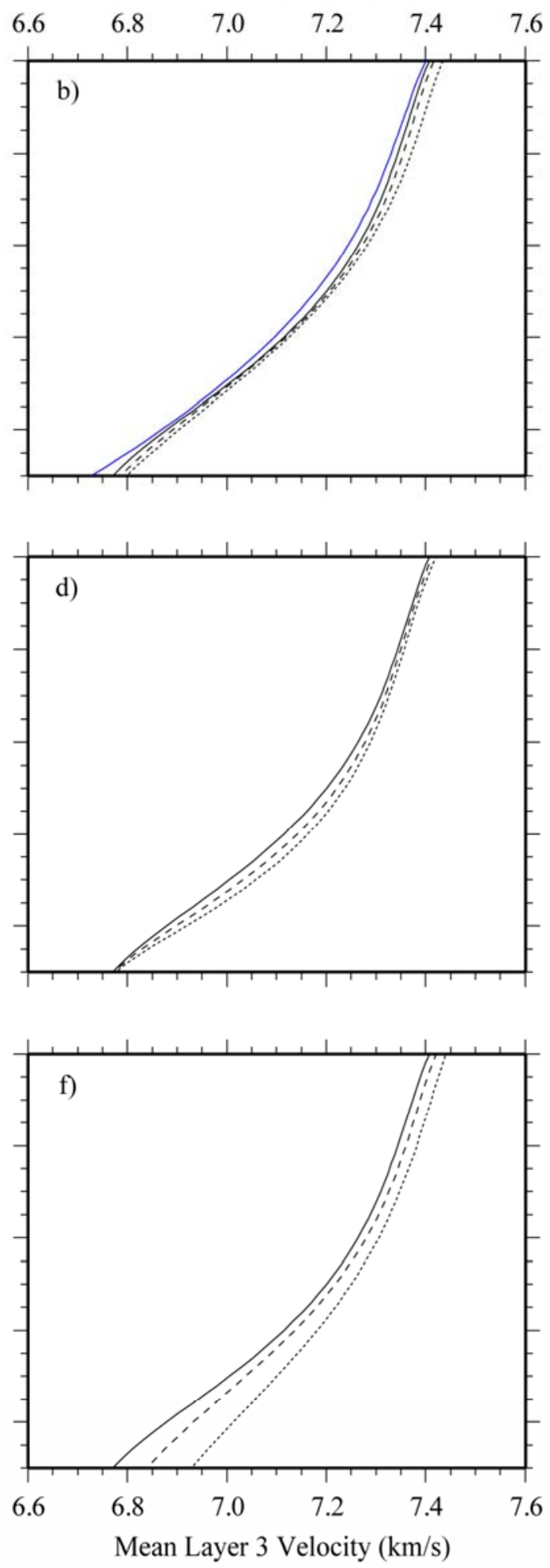

Figure 4 
Crustal Thickness (km)
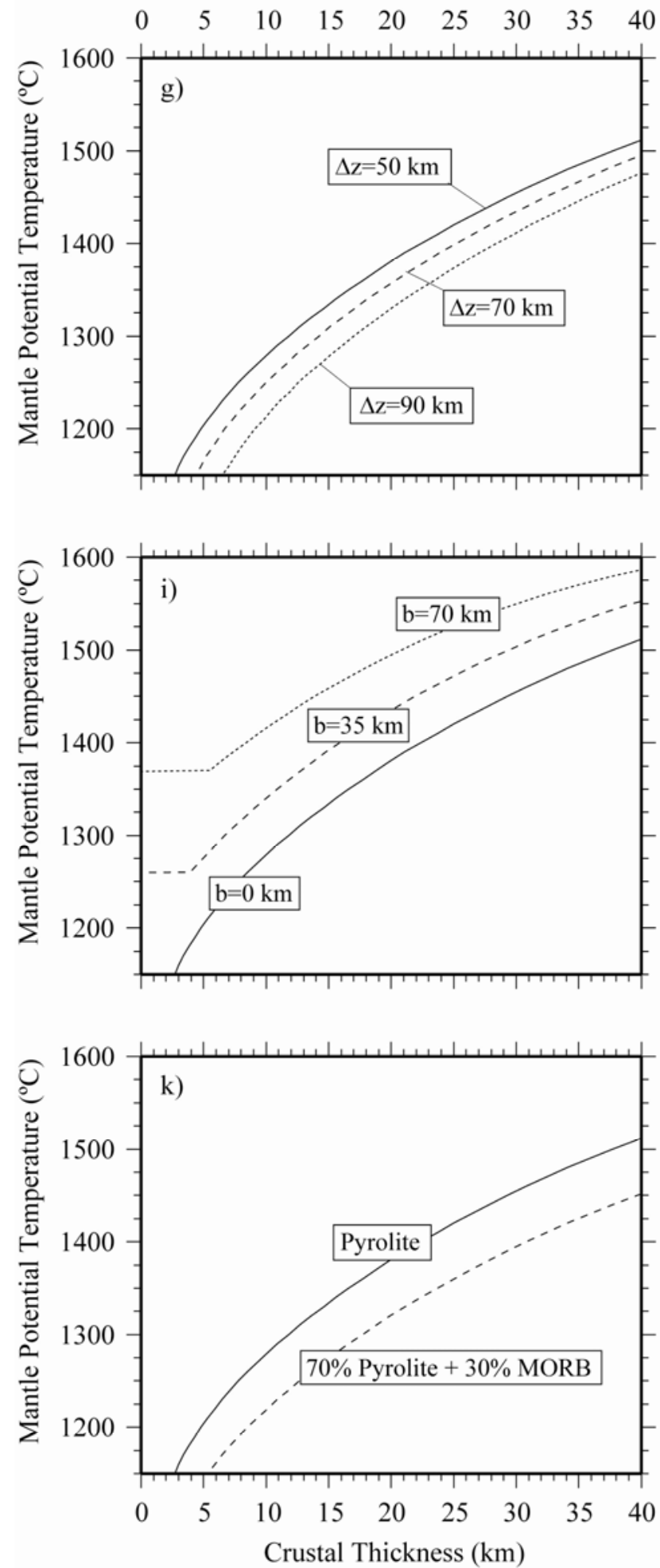

Mean Layer 3 Velocity $(\mathrm{km} / \mathrm{s})$
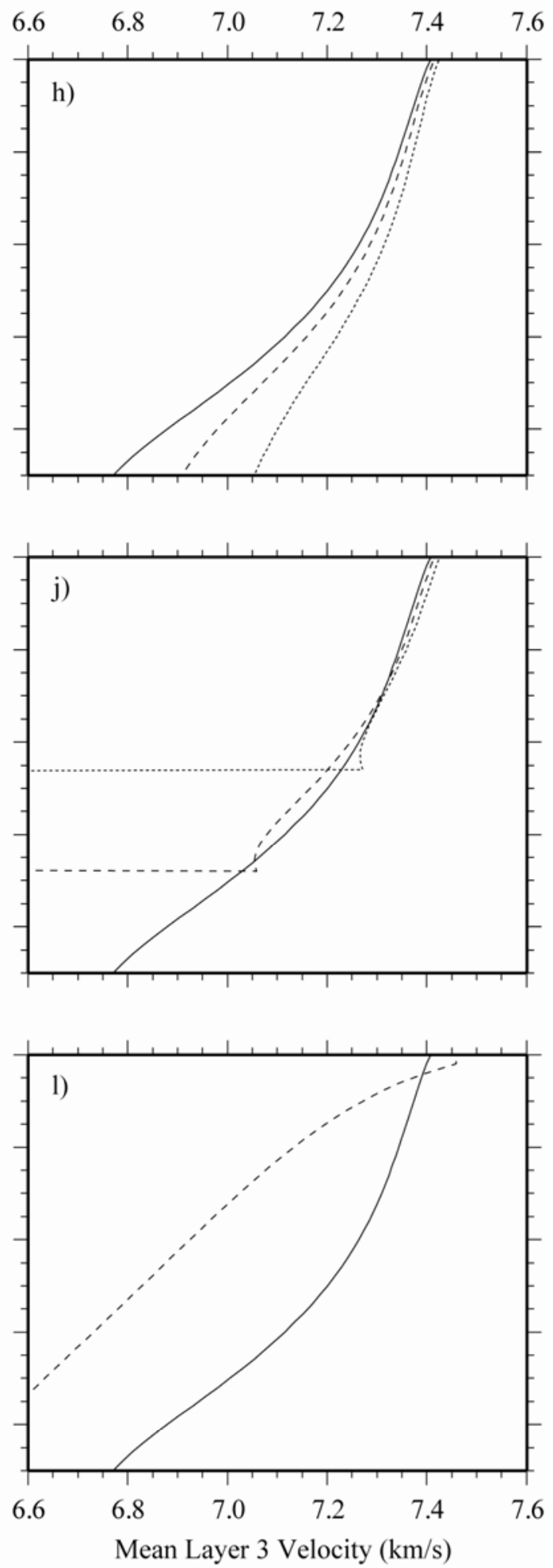

Figure 4 